DEPARTMENT OF THE INTERIOR

U.S. GEOLOGICAL SURVEY

\title{
Mesozoic biogeography of southern Alaska \\ with implications for the paleogeography
}

By

Robert L. Detterman ${ }^{1}$

Open-File Report 88-662

This report is preliminary and has not been reviewed for conformity with U.S. Geological Survey editorial standards and stratigraphic nomenclature. Any use of trade names is for descriptive purposes only and does not imply endorsement by the USGS.

$1_{\text {Menlo Park, California }}$ 


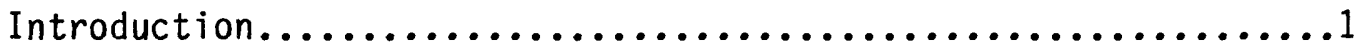

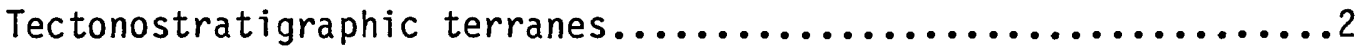

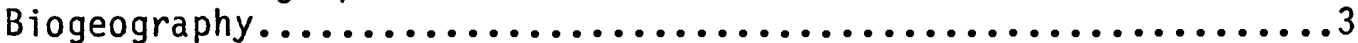

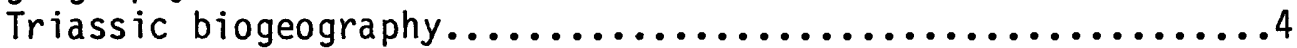

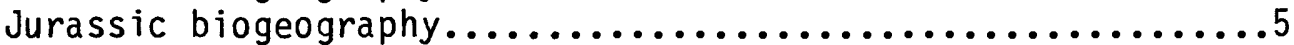

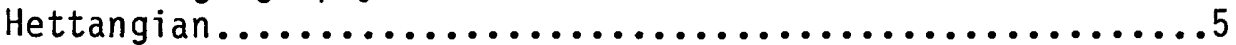

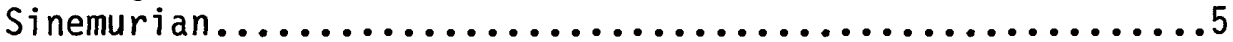

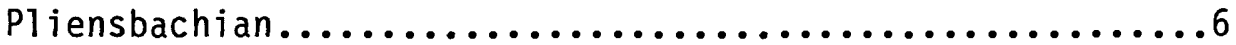

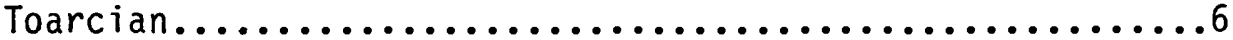

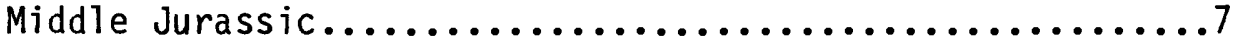

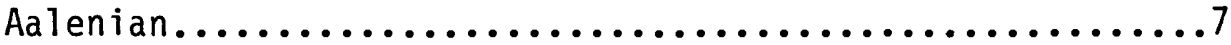

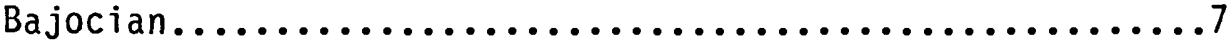

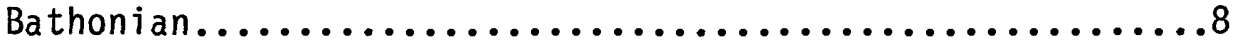

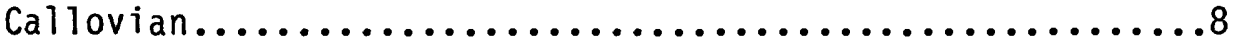

Oxfordian, Kimmeridgian, and Tithonian...............8

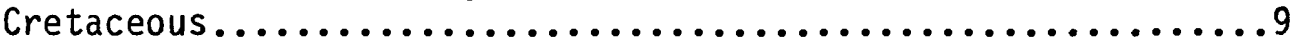

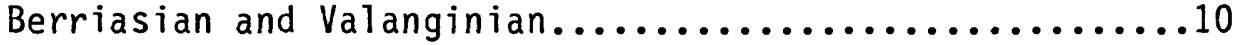

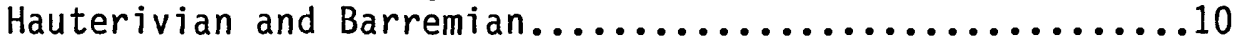

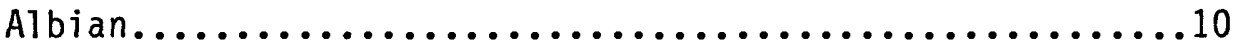

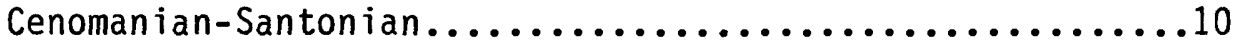

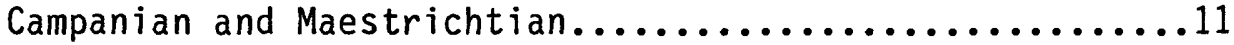

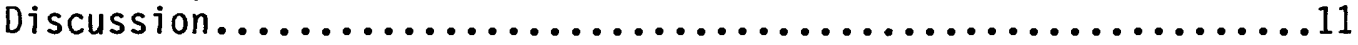

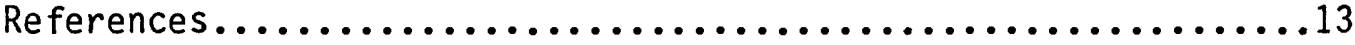

Figures

Figure 1. Tectonostratigraphic terranes of southern Alaska

2. Schematic stratigraphic sections of selected terranes, southern Alaska

3. Biogeograhic terminology for southern Alaska

4. Biogeography for the Hettangian

5. Biogeography for the Sinemurian

6. Biogeography for the Pliensbachian

7. Biogeography for the Toarcian

8. Biogeography for the Aalenian

9. Biogeography for the Early Bajocian

10. Biogeography for the Late Bajocian

11. Biogeography for the Early Bathonian

12. Biogeography for the Late Bathonian

13. Biogeography for the Callovian

14. Biogeography for the 0xfordian, Kimmeridgian and Tithonian

15. Buchia biozones in southern Alaska

16. Biogeography for the Berriasian and Valanginian

17. Biogeography for the Hauterivian and Barremian

18. Biogeography for the Albian

19. Biogeography for the Cenomanian-Santanian

20. Biogeography for the Campanian and Maestrichtian 
Mesozoic biogeography of southern Alaska,

By

Robert L. Detterman

\section{Introduction}

That southern Alaska is a collage of accreted tectonostratigraphic terranes is now well-documented in numerous publications (Jones and others, 1977, 1978; Berg and others, 1978; Coney and others, 1980; Csejtey and others, 1982). What is less well documented is the itinerary and arrival time for the various terranes. Paleomagnetic data has been used almost exclusively to plot the path and timing of these events, and much data has been published (Coe and others, 1985; Hillhouse, 1977; Hillhouse and Gromne, 1982 and 1985; Jones and others, 1977, 1978; Packer and Stone, 1974; Panuska and Stone, 1985; P1umley and others, 1983; Stone and Packer, 1977 and 1979; Stone and others, 1982). In general, all of the paleomagnetic data indicated a northward migration for al1 of the terranes, however, some of the data suggested a very erratic course for a few of the terranes, but with an overall northward component. Nearly all published paleomagnetic data includes a statement on the reliability of the samples. Many factors can effect the reliability including but not 1 imited to errors in age-dating the rock sampled, or in demagnetising the sample, incorrectly measuring the strike or inclination of the bed. Lava flows are probably the most reliable source of data; but many samples are collected from sedimentary rocks where such things as bioturbation, compaction, or slumping can effect the inclination and orientation of magnetic minerals.

The apparent ambiguities in paleolatitude and paleolongitude resulting from paleomagnetic data suggests that biogeographic data should be considered in conjunction with paleomagnetic data to obtain a more precise estimate of the origin of the allochthonous terranes as well as the timing of their accretion to southern Alaska. That is the purpose for this discussion on the biogeography of the Mesozoic of southern Alaska. For this discussion southern Alaska is defined as the general area south of the Denali Fault, but here excluding southeastern Alaska (Fig. 1).

The stratigraphy of the terranes comprising southern Alaska is fairly we11 known. Some terranes have been studied in much greater detail than others, particularly Wrangellia and Peninsular, but overall the Mesozoic sequence has been determined (Fig. 2). It is obvious from figure 2 that many similarities, as we11 as many dissimilarities, exist in the stratigraphic sequence between the various terranes. The dissimilarities, are to be expected if the terranes are truly exotic. Conversely similarities should indicate a time when the segments were joined.

Biogeographic data has previously been used to document the movement of some terranes in southern Alaska (Jones and others, 1980, Nichols and Silberling, 1979, and Silberling, 1985). Southern Alaska was also included in a general paper on the Jurassic biogeography of western North America by Taylor and others (1984).

Biogeographic data presented here on the direction and timing of the 
movements of southern Alaska terranes may prove to be unduly precise. However, the rate of movement is not unreasonable. During Late Triassic (Norian) time the terranes were far to the south. Paleomagnetic data indicates at about $15^{\circ}$ (Hillhouse, 1977), but does not distinguished between north and south latitude. The lithology and fauna of the Triassic rocks corroborates the low latitude, but indicates a definite northern hemisphere location. The biogeographic data further suggest the terranes were in approximately their present latitudinal position by Middle Jurassic (late Bajocian) time. Thus, the terranes traveled northward about $4000 \mathrm{~km}$ in approximately $45 \mathrm{Ma}$, or about $8.8 \mathrm{~cm} /$ year. This rate is no faster than some of the postulated current plate movements (Moore, 1982).

Biogeography can be a powerful tool for interpreting the paleo-geographic position of allochthonous terranes. In many cases it can determine latitudinal changes more precisely than paleomagnetics, which commonly indicates a latitude that may be in either the southern or northern hemispheres. For biogeographic analys is to be useful it needs to be based on taxonomic groups collected from well controlled sections, and whose geographic range is known. Ammonoids are particularly useful for biogeographic analysis, in large part because of the great diversity of genera, rapid evolution, and for many genera a restricted latitudinal and longitudinal range. The Mesozoic strata of southern Alaska, especially the Peninsular and Wrangellia terranes, contain abundant ammonoids, with the notable exception of the uppermost Jurassic and lowermost Cretaceous. However, this latter interval contains an abundant bivalve fauna (Buchia) that is also useful for paleo-geographic as well as chronostratigraphic interpretations (Miller and Detterman, 1985). In order to make solid biogeographic determinations it is necessary to have numerous specimens of as many genera as possible. Ammonites were freeswimming, and single specimens may indicate a spurious faunal province, because a solitary specimen may have lived far distant from the site at which it was deposited. The ammonites and bivalves used as the bases of this report includes 2,390 occurrences of 109 genera and 257 species of ammonites and three pelecypod genera with 598 occurrences of 10 species. The genera are 1 isted by age and faunal realm.

Identification of and biogeographic data for the numerous Jurassic ammonoids was mainly by Imlay $(1953,1961,1964,1980 a, 1980 b, 1981,1984 a$, 1984b); Imlay and Detterman (1973), and Westermann, (1964, 1969), and Callomon (1984). Chronostratigraphically important bivalves from the Upper Jurassic and Lower Cretaceous were identified by John W. Miller. Upper Cretaceous ammonoids were identified by Jones $(1963,1967)$. The Triassic fauna was identified by N.J. Silberling.

\section{Tectonostratigraphic Terranes}

The Togiak terrane is based primarily on the work of Hoare and Coonrad (1978) and is mainly a turbidite deposit of graywacke, conglomerate, siltstone, argillite, with minor pillow basalt and flows. The Mesozoic age range is Late Triassic to Late Cretaceous. The only Jurassic fauna obtained are a few bivalves. The adjoining Goodnews terrane contains some of the same age strata, but is less well known and is not included here.

The Flysch terrane originally termed upper Mesozoic flysch by Jones and others (1981) is poorly known due to poor outcrops and highly deformed rocks. Recent work by Reed and Nelson (1977) has confirmed a sequence of graywacky siltstone, and pillow basalt of Early Jurassic to Early Cretaceous 
age. Some late Mesozoic flysch may be present, also, but has not been confirmed.

The Chulitna terrane (Jones and others, 1980; Nichols and Silberling, 1979 ) is an exotic terrane in southern Alaska. Triassic red beds occur in only this one area of Alaska, where they are associated with limestone and overlying argillite, chert, siltstone and shale of Jurassic and Cretaceous age. All of which rest on an ophiolitic basement and on limestone of Devonian to Permian age.

The Peninsular terrane has probably been studied in greater detail than any of the other Mesozoic terranes of southern Alaska (Detterman and Harsock, 1966; Detterman and Reed, 1980; Detterman and others, 1981a, b, 1985, 1987 ; Imlay, 1980a, b, 1981, 1984a, b; Jones and Grantz, 1967; Riehle and others, 1987; Wilson and others, 198). The Peninsular Terrane can be divided into two sub-terranes, Iliamna and Chignik, which are separated by a major fault (Bruin Bay fault) (Wilson and others, 1985). The Iliamna sub-terrane northwest of the fault is mainly an early Mesozoic volcanic-plutonic arc invading a Triassic sequence that is now partly metamorphosed. The Chignik sub-terrane, east of the fault is primarily a platform clastic sequence of Late Triassic to Late Cretaceous age.

Wrangellia was first defined as an exotic terrane by Jones and others (1977, 1978; Hillhouse 1977). The Mesozoic stratigraphy consisting of Triassic limestone overlying greenstone and succeeded by Jurassic and Cretaceous clastic rocks of both deep and shallow marine origin. Wrangellia has been studied in considerable detail by MacKevett (1978) and Richter (1976).

The geology and paleomagnetics of the southern Alaska terranes suggest that some may have coalesced before final docking. Jones, and others (1978) and Stone and others (1982) consider that the amalgamation of Wrangellia and Peninsular terranes was accomplished by Middle Jurassic time. An earlier amalgamation was suggestd by Detterman and Reed (1980) based on similarities in the Triassic sequence. Biostratigraphic analysis presented here adds further evidence that the two terranes were part of a single unit before docking on the craton in Middle Jurassic time. This would imply that all terranes lying inboard of the Peninsular and Wrangellia terranes were also in place by the middle Jurassic.

\section{Biogeography}

The biogeographic provinces used in this report for southern Alaska (Fig. 3) are modified after Taylor and others (1984), and are primarily for ammonite genera that are either confined to a restricted area or characteristic of one in which they are more widespread, diverse, or abundant. Ammonites are abundant in the southern Alaska Mesozoic, except for a few stages of the Upper Jurassic and Lower Cretaceous. In these occurrences informative bivalve distribution will be used.

Faunal provincialism during the Mesozoic reached its greatest development in the Jurassic. Three realms, Boreal, Tethyan, and East Pacific, of Tayor and others (1984) are identified (Fig. 3). The realms can be subdivided further into provinces (Taylor and others, 1984), each with its distinctive fauna, which are critical to the biogeographical reconstruction of the tectonostratigraphic terranes of southern Alaska. The Boreal, Sub-Boreal, and Bering are the provincial components of the Boreal Realm. The Boreal Province is identified by its close ties, in many cases to the specific level, with the 
fauna in Greenland, northern Canada, northern Europe, and Siberia. The SubBoreal Province is correlated mainly with Europe, and the Bering is characterized by fauna restricted to areas around the north eastern Pacific Ocean. Boreal Realm taxa are of particular relevance in placing constraints on the movements of terranes, because they are indicative of comparatively high paleolatitudes (north of $45^{\circ}$ ).

Fauna of the Tethyan Realm are found worldwide in low to middle latitudes (equator to about $30^{\circ}$ north and south), but do not necessarily indicate a direct connection with the Tethys Sea. The Caribbean Province of the Tethyan includes fauna from Mexico, or the Gulf Coast and Cuba.

The East Pacific Realm includes two provinces of relevance to southern Alaska, Athabascan and Shoshonean, which are included in the North Cordilleran Region (Taylor and others, 1984). The Athabascan Province contains taxa that are primarily confined to allochthonous terranes of northwestern North America, whereas the Shoshonean Province is mainly of cratonic North America.

The informal grouping of taxa termed pandemic includes those taxa that are particularly widespread without apparent latitudinal restraints. Pandemic taxa, therefore, are of lesser value in determining paleolatitudes than are the more restricted fauna.

\section{Triassic Biostratigraphy}

Most of the fault-bounded tectonostratigraphic terranes of southern Alaska contain Triassic strata (Fig. 2). Limestone chert, and volcanic rocks including some pillow basalts are common to most terrrnes (Fig. 2), and many similarities are immediately evident suggesting deposition under similar conditions associated with a volcanic arc. There are some significant dissimilarities such as the exotic red bed clastic rocks of the Chulitna terrane (Jones and others, 1980). Most variations between the stratigraphy of the other terranes can be explained by facies changes and deposition in water of different depths, and do not necessarily indicate that the terranes were widely separated before accretion to Alaska. Two of the terranes, Wrangellia and Peninsular, were closely associated, if not joined, during the Triassic. Both terranes contain thick mainly subaerial basalt (Nikolai Greenstone in Wrangellia and Cottonwood Greenstone in Peninsular terrane) that overlies Permian limestone and underlies Triassic limestone. In both terranes the greenstone sequence is overlain by limestone containing a fauna that exhibit many similarites.

Paleomagnetic investigation of the Nikolai Greenstone in Wrangellia indicates it was deposited far to the south (Hillhouse, 1977; Jones, Silberling, and Hillhouse, 1977, 1978), and that it has moved approximately $3,000 \mathrm{~km}$ northward from a depositional site at about $15^{\circ} \mathrm{N}$. The $95-$ percent confidence limits are between $5^{\circ} \mathrm{N}$ and $26^{\circ} \mathrm{N}$, assuming a normal polarity. If the polarity were reversed the depositional site would be in the southern hemisphere. Paleomagnetic data has not been obtained from the Cottonwood Greenstone.

Lithologic features of the southern Alaska Triassic rocks indicate a more southerly depositional site than their present location. Thick sequences of limestone, part of which was deposited under sabkha conditions, (Armstrong and Mackevett, 1982) can only be deposited in a near tropical climate.

Faunal elements in these Triassic rocks also suggest, a lower latitude. Some of the main elements of this fauna include the ammonites Meekoceras 
gracillitatis, Tropites welleri, Indojuvavites sp., Juvavites sp., Halorites sp., Metasibirites sp., Alloclionites sp., and Pseudosirenites sp., the pelecypods, Halobia dilatata Monotis subcircularis, M. salinaria, and the hydrozoan Heterastridium sp., plus, many corals and gastropods. Most of this fauna, except corals and gastropods were free-swimming, floating, or attachedfloating forms that could be widely dispersed after death but probably not by the $3,000 \mathrm{~km}$ that these rocks are assumed to have moved based on paleomagnetic evidence. Silberling (1985) presents further evidence for the northward movement of these terranes based on the association of Monotis subcircularis and Monotis salinaria.

\section{Jurassic Biostratigraphy}

The rapid world-wide evolution of ammonites during the Jurassic was accompanied by the development of provincialism that make this taxon of great importance in determining paleolatitude and to a lessor extent paleolongitude. This in turn can be used in the reconstruction of the paleogeography of the allochthonous terranes of southern Alaska. The RealmRegion-Province biogeographic terminology (Fig. 3) of Taylor and others (1984) will be used for this discussion. Nearly 800 collections of Jurassic fauna were obtained as a result of recent investigations of the Peninsular Terrane, and greatly reduce the possibility that breaks in the stratigraphic sequence are due to artifacts of collecting.

In the following discussion a number following the name will indicate occurrences for each genera.

\section{Hettangian}

Hettangian ammonites in southern Alaska are known only from the Wrangellian and Peninsular terranes (Fig. 4). Most specimens are from the Peninsular Terrane at Puale Bay, on the Alaska Peninsula. Where few genera are represented, but there are numerous specimens of each genera. Most are characteristic of the informal Pandemic Realm, including Psiloceras, (7) Schlotheimia (2), and Waehneroceras (16) which have a wide distribution including Europe, and generaliy overlaps with the Tethyan Realm. The latter is represented by Discamphiceras $(7)$, which along with a 1 imy sandstone and limestone could suggest deposition in warm marine seas at lower latitude. There are no Hettangian ammonites with Boreal affinities known from southern Alaska. Likewise, there are no known ties to genera found south of the equator, but the presence of the Tethyan ammonite Discamphiceras and the associated pandemic genera indicated a strong Tethyan affinity for the Hettangian strata in southern Alaska. Consequently, the best estimate for a depositional site would be at low latitude $\left(10-30^{\circ}\right)$, but north of the equator as none of these genera are found south of the equator.

\section{Sinemurian}

Sinemurian ammonites were considerably more widespread in southern Alaska than was the case during the Hettangian (Fig. 5). Most of the genera with the greatest number of individual specimens are Pandemic forms including Arnioceras (21), Cornoniceras (7), Crucilobiceras (6), Paltechioceras (6), and PsiToceras (2). The Tethyan Realm is based mainTy on Discamphiceras (2) and Paracaloceras (7), which are fairly common in the Peninsular Terrane, but 
elsewhere in southern Alaska is represented by a few widely scatterred occurrences. The distinctive bivalve Weyla (13) is included in the Tethyan, it is the only form found in the Togiak Terrane and is the only common form in the Flysch Terrane. Bodouxia (7) and Arctoasteroceras (3) are found in the Athabaskian Province of the East Pacific Realm from California north to Alaskan as well as in eastern Siberia. In southern Alaska they are restricted to a few widely scattered occurrences in the Peninsular and Chulitna Terranes.

During Sinemurian time ammonites in southern Alaska started to show greater diversity than was evident previously, but pandemic forms were still the main constituents of the fauna (Fig. 5). The Tethyan pectinid bivalve Weyle has to be considered a major indicator of paleolatitude as it was less mobite than the free-swimming ammonites, and it is present in most of the southern Alaskan terranes where it occurs with Discamphiceras, giving these beds a strong Tethyan affinity. As a consequence, these terranes during the Sinemurin were probably at least $2,000 \mathrm{~km}$ south of their present location, but were located in the eastern Pacific as indicated by the presence of Bodouxia and Arctoasteroceras.

\section{PTiensbachian}

Strata of Pliensbachian age are restricted to the northeastern part of the Peninsular Terrane (Grantz, 1960, 1961) and the the adjoining parts of Wrangellia (Fig.6). Pandemic ammonites including Apoderoceras (2), Leptaleoceras (1), Peltarpites (1), Prodactilloceras (5), and Tropidoceras (1) are common particularly in 1ate Pliensbachian time. Uptonia (7) is the onty early Pliensbachian pandemic. Tethyan fauna are more abundant in the upper part of the stage with Arieticeras (7), Fontanelloceras (3), and Protogrammoceras (5) occurring at several localities. However, the overall character of the Pliensbachian taxa is pandemic.

The first indication of the Boreal Realm (Fig. 6) in southern Alaska is furnished by several specimens of Amaltheus from the Peninsular Terrane in the Talkeetna Mountains, where they occur in beds of late Pliensbachian age. These are isolated occurrences associated with mainly pandemic and Tethyan taxa and probably have limited value in determining paleolatitude but they do suggest that the Peninsular Terrane was not in the tropics during late Pliensbachian time, but probably was well south of its present position. Fanninocerasis (5) is a genus restricted to the eastern Pacific area; it is found associated with Amaltheus and such Tethyan genera as Arieticeras and Fontanelliceras in the Talkeetna Mountains (Imlay, 1981).

\section{Toarcian}

Provincialism of the ammonite taxon in terranes comprising southern Alaska was nonexistent during the Toarcian (Fig. 7). The ammonites Dactylioceras (3), Grammoceras (1), Harpoceras (1), Haugia (9), Peronoceras (1), and Phymatoceras (2) can best be considered as pandemic forms that occur worldwide. Toarcian strata are positively identified only in the Peninsular Terrane with one questionable occurrence in Wrangellia. Nearly all of the fauna are from the Talkeetna mountains (Imlay, 1981) where Dactylioceras and Haugia form the main constituents of the fauna. The dactyliocertids including both D. commune, of Arctic Canada, and D. kanense, of Oregon and southern Canada, are present in the Talkeetna Mountains. These species of Dactylioceras, especially D. commune with high latitude affinities, and in the 
absence of any Tethyan ammonites, may indicate that the Peninsular Terranes had moved northward by late Early Jurassic time.

\section{Middle Jurassic Aalenian}

The Aalenian Stage, at the base of Middle Jurassic, is marked in southern Alaska by a great diversity of ammonites that have a very well-developed provincialism containing numerous representatives of both Tethyan and Boreal Realms (Fig. 8). The abundance of ammonites probably indicates proximity to the open ocean as suggested by Callomon (written commun. J.H. Calloman, 1981). Two genera, Erycitoides (67) and Pseudolioceras (20), that are restricted to the Bering Province of the Boreal Realm (Taylor and others, 1984), account for over 50 percent of the fauna collected. Both genera contain several species (Imlay, 1984b, and Westermann, 1964). The numerous specimens of Erycitoides and Pseudolioceras, particularly P. maclintocki, which is commonly found in the high-Arctic regions (Taylor and others, 1984), would indicate either a rapid southward expansion of Boreal faunal elements or that the Peninsular terranes was already near its present position by the middle Jurassic. Tethyan fauna such as Abbasites (6), Asthenoceras (2), Eudmetoceras (21), Fontannesia (2), and Planammetoceras (3) are subordinate to both Boreal and pandemic forms in the strata of southern Alaska.

\section{Bajocian}

The ammonite fauna flourished and expanded greatly in the Peninsular Terrane during early Bajocian time (Fig. 9). This abundant fauna was completely cosmopolitan with elements of the Boreal, Tethyan, and East Pacific Realms freely mingling with Pandemic forms, however, Pandemic and Tethyan elements predominated. The pandemic taxa were by far the most abundant including Stephanoceras (18), Sonninia (13), Chondroceras (23). Witchellia (8) Docidoceras (25) and Bradfordia (19) of the Tethyan Realm were moderately abundant and this stratigraphic interval has been termed the Docidoceras widebayense Zone by Westermann (1969). The Boreal ammonite Pseudolioceras (2) is found 1ocally, but Arkelloceras (1) is found only rarely in strata of southern Alaska.

Provincialism became restricted in southern Alaska during late Bajocian time. (Fig. 10) with elements of the Athabskan Province of the East Pacific Realm, such as Megasphaeroceras (12) and Parareineckia (8), being associated with pandemic forms like Stepnanoceras (8), Oppelia (2), Normannites (28), and Leptosphinctes (3). Tethyan fauna were no longer present in southern Alaska Terranes, and there is no evidence for them during the remaining stages of the Jurassic.

It should be mentioned here that two genera of Jurassic ammonites, Phylloceras and Lytoceras, are common in the southern Alaska Bajocian strata, and they continue on into the latest Jurassic beds where they are the only ammonites found and are associated with the Boreal bivalve Buchia. Both Phylloceras and Lytoceras were originally considered to be indicators of the Tethyan faunal realm, but their continued presence in many parts of the world with Boreal Realm fauna cast doubt on that assumption. Recent work by Calloman (1984) has shown that these ammonites were pelagic ocean-dwellers rather than shelf-dwellers and that their presence merely indicated access to the open ocean. Neither Phylloceras nor Lytoceras are included in this 
discussion of the southern Alaska terranes in as much as they do not represent a specific faunal realm.

Some conclusions concerning the paleolatitude of these terranes can be drawn from the abundant fauna. The complete disappearance of Tethyan elements by late Bajocian time and the predominance of a cosmopolitan and Boreal fauna indicates these rocks were well north of the equator at the time of deposition. Information on the paleolongitude can be obtained, also, as Megasphaeroceras and Parareineckia are East Pasific Realm ammonites (Taylor and others, 1984).

\section{Bathonian}

Boreal and East Pacific Realm ammonites flourished in Early Bathonian time (Fig. 11). Both the Boreal and Sub-Boreal Provinces are represented in the Peninsular Terrane by Arctocephalites (4) and Kepplerites (10). The absence of Kepplerites in Wrangellia is probably due to a minor depositional hiatus or post-depositional erosion. Endemic East Pacific ammonites such as Cranocephalites (67), Iniskinites (1), and Parareineckia (22) are represented by numerous specimens, and all belong to the more northerly Athabascan Province.

The Late Bathonian saw a marked decrease in genera present in southern Alaska, and there only in the Peninsular Terrane (Fig. 12). The first occurrence of the Boreal Province ammonite, Cadoceras (6), is recorded from these strata where it is associated with Sub-Boreal Kepplerites (5) and the East Pacific Iniskinites (8). Cadoceras is by far the most important paleolatitudinally, of the genera in the Peninsular Terrane; it is found throughout Greenland, northern Europe, Siberia, and northern Canada. These fauna thus strongly suggest that southern Alaska was near or at its present position by late Bathonian time.

\section{Callovian}

During the Callovian the number of ammonite genera was greatly restricted and they have been identified in only the Peninsular Terrane, where numerouus specimens of Cadoceras (133) and its sub-genera Paracadoceras (20), Stenocadoceras (67), and Pseudocadoceras (70) local1y occur in great abundance. A few specimens of the Sub-Boreal Kepplerites (34) as well as Lilloetia (29) of th East Pacific Realm occur throughout the terrane. Access to the open ocean during the Callovian was probably limited to the Peninsular Terrane with other terranes undergoing erosion or nondeposition, as did the Peninsular Terrane during late Callovian. There is no faunal evidence of upper Callovian strata in southern Alaska.

The bivalve Inoceramus ambiguus is associated with the ammonite fauna throughout the Peninsular Terrane. This bivalve is common, also in other high-latitude areas of Callovian strata (Detterman and others, 1975; Poulton, 1978; Callomon, 1984).

\section{Oxfordian, Kimmeridgian, and Tithonian}

Southern Alaska terranes contain a very sparse ammonite fauna during Late Jurassic time. The only ammonites of regional significance in the Peninsular Terrane was the Boreal Realm Cardioceras (11) with its sub-genera Scarburgiceras (3) and Scoticardioceras (2), all of which were moderately 
abundant in 0xfordian strata in the Cook Inlet area (Fig. 14). Amoeboceras (3) occurs in Wrangellia with bivalves that indicate a Kimmeridgian age for the enclosing strata (MacKevett, 1971). Of interest is the continued occurrence in these upper Jurassic rocks of Phylloceras and Lytoceras, but for reason already stated these ammonites are not included in this discussion.

The Boreal epifaunal bivalve Buchia is found in great abundance throughout upper Jurassic and lower Cretaceous strata in southern Alaska. These bivalves occur in all depositional environments, but are found in greatest abundance in deposits considered to represent open shelf deposits. This was probably a time of rapid marine transgression in southern Alaska with attendant development of numerous species of Buchia, many from well-controlled measured sections. This new data permit a biozonation of Buchia (Fig. 15) that is useful in southern Alaska. These zones add to, and complements, previously defined Buchi zones in western North America (Imlay 1959; Jeletsky, 1965; Jones and others, 1969; Miller and Detterman, 1985).

The Buchia zones are tied to ammonites in that the oldest form in Alaska, Buchia concentrica, occurs with Cardioceras in the Cook Inlet area of the PeninsuTar Terrane. Additionally, Buchia mosquensis is found in Wrangellia with Amoeboceras, and in all of southern Alaska, Simberskites of Hauterivian (Lower Cretaceous age) overlies strata that contain the youngest form of Buchia (B. Crassicollis). In this respect Buchia biozones are a valuable stratigraphic tool.

Buchia cooncentrica and the first occurrence of $B$. rugosa are found mainly in fine clastic siltstone and shale indicative of a moderately deep outer shelf marine environment, and the fauna is very sparse. As the depositional environment changed to inner shelf with more coarse clastic sandstone the fauna underwent rapid development with abundant individuals. Some horizons contain thousands of specimens.

The important paleolatitude implications of this abundant Buchia fauna is that it is strictly a Boreal Realm taxa that is found throughout the northern hemisphere. The Boreal Realm did expand rapidly southward during the Late Jurassic. An expansion that carried some elements of the taxa as far south as Mexico where ammonites were moderately abundant.

In conclusion the biogeographic data from Peninsular and Wrangellian terranes suggest they were near or at their present position by middle Jurassic (Bajocian) time. Data from the other allochthonous terranes in southern Alaska do not add much in this respect, but their position inboard of he Peninsular and Wrangellian terranes indicate they had arrived prior to the Peninsular and Wrangellian terranes.

\section{Cretaceous}

The prolific and diverse ammonite fauna with its marked provincialism characteristic of much of the Jurassic was lacking in southern Alaska throughout most of the Cretaceous. The ammonites staged a comeback during Late Cretaceous time but for the most part provincial forms were subordinate to pandemic forms. Both ecological and environmental factors probably were contributing factors to the poor representation of ammonites. The sedimentary environments, particularly in the lower Cretaceous, were primarily of inner shelf and restricted basinal environment. Access to the open ocean was probably limited and consequently the free-floating ammonites would be restricted. 
The bivalve Buchia continued to thrive and diversify into different species in the shelf environment present in southern Alaska. Evidence for the development of this genus is best preserved in the Peninsular Terrane where Buchia okensis, B. uncitoides, B. sublaevis, and B. crassicollis solida are all found in stratigraphic succession during the Berriasian and valanginian (Figs. 15 and 16). Other terranes in southern Alaska contain evidence only of the Valanginian Buchia crassicollis solida. The genus Buchia became extinct at the end of the Valanginian, and was replaced by Inoceramus, which occupied the same general ecological niche. The genus Buchia is an indicator that the Boreal Realm was present in southern Alaska, and the absence of any fossils with southern affinities would suggest these rocks were in northern latitudes during this part of the Cretaceous.

\section{Hauterivian and Barremian}

Ammonites and the bivalve Inoceramus of the Hauterivian and Barremian stages are best considered as Pandemic fossils (Fig. 17) as they are present in many areas of the world (Moore, 1959). However, at the species level these fossils all have strong affinities to Pacific forms. The ammonites Simbirskites (2), Hoplocrioceras (2), and Acrioceras (1) occur sparsely in these strata along with Inoceramus ouatoides (4). In most localities the strata are composed of shell fragments and prisms that constitute 30 to 70 percent of the rock. These strata have been termed Herendeen Formation (Detterman and others, 198_) on the Alaska Peninsula, and Nelchina Limestone (Martin, 1926) in the Talkeetna Mountains. In both cases the rocks are calcarenites and calcareous sandstone rather than limestone.

\section{Albian}

Ammonites became reestablished in southern Alaska during the Albian Stage reaching their greatest proliferation since the Middle Jurassic (Fig. 18). Aptian rocks are not recorded in southern Alaska, so possibly this revival started earlier. Most of the taxa are from the northeastern part of the Peninsular Terrane and the adjoining part of Wrangellia, showing conclusively that these terranes were joined at that time. The ammonite genera listed in figure 18 as Boreal Realm (Arcthophlites (5), Moffities (18), and Grantziceras (16 sub-genus of Beudanticeras) probably should be considered a sub-Boreal Realm as they are mainly restricted to southern Alaska (Imlay, 1960), where they are associated with an East Pacific Realm fauna characterized by Brewericeras (20) and Hulenites (7) that extend southward as far as northern California (Imlay, 1960). The pandemic genera Pseudouhligella (19) is also common in southern Alaska. The preponderance of biostratigraphic evidence indicates these terranes were at or near their present position at this time.

\section{Cenomanian-Santonian}

Early Late Cretaceous strata are present only in the northeastern part of the Peninsular Terrane and the adjoining part of Wrangellia (Fig. 19). Elsewhere in southern Alaska this interval has not been identified. Where present, the 500 to $1000 \mathrm{~m}$ of fine clastics, siltstone and shale, contain a 
fairly prolific ammonite fauna associated with the bivalve Inoceramus.

The ammonites are mainly of the Pacific Realm including Desmoceras (10) (Pseudoughligella), Mesopuzosia (4), Otoscaphites (2), and Parajaubertella (1). Some of the fauna is restricted to the north Pacific, particularly with Japan, such as Yokoyamoceras (2). The numerous inoceramids al so have close ties to Japan. Only a few pandemic ammonites are present including Gaudryceras (2) and Tetragonites (3).

The marked North Pacific provincialism of the taxa in the Peninsular and Wrangellian Terranes indicate that the strata were deposited at or near their present latitude. The longitudinal position can not be determined precisely. The inoceramids are found abundantly in the western interior of the United States and Canada, as well as in areas bordering the western Pacific such as Japan. Consequently, the fauna do not indicate, or negate, a shift in longitude. The evidence for latitudinal change based on fauna is more precise; it has not changed markedly from its present position.

\section{Campanian and Maastrichtian}

Endemic Pacific Realm provincialism continued to flourish in the ammonite and bivalve taxa of southern Alaska during the latest Cretaceous stages. The bivalve Inoceramus was strongly North Pacific in character and proliferated into numerous species including Inoceramus schmidt, I. subundatus, I. kusiroensis, I. balticus var kunimienss, I. naumani, I. orientalis, and I. shikotanensis. Most of the inoceramids have a strong affiliation with Japanese species, as well as British Columbia and California. Among the ammonites, particularly Canadoceras (38), Diplomoceras (36), Eupachydiscus (20), and Pachydiscus (39), there are close ties with these same areas. In all cases, however, there are fewer species represented in southern Alaska collections than in other areas.

\section{Discussion}

The biostratigraphic data presented here is not to be construed as the sole answer to the depositional site of, or the time of accretion of, the terranes to Alaska, but the data does indicate another line of evidence that should be considered when discussing the movement of the southern Alaska terranes. Biostratigraphic data corroborates paleomagnetic data for the lower Mesozoic (Triassic and lower Jurassic) both indicate a position far to the south for the terranes. However, biostratigraphy indicates a northern hemisphere source rather than an ambiguous either/or (northern or southern) hemisphere suggested by paleomagnetic data.

Triassic rocks are present in most of the tectonostratigraphic terranes in southern Alaska (Fig. 2). They have many lithologic similarities including thick limestone and chert sequences interbedded with pillow basalt or volcanic flows, and in the Peninsular and Wrangellian Terranes a thick greenstone sequence underlying the limestone and overlying Permian limestone. The Peninsular Terrane and Wrangellia are so nearly the same as to suggest they are part of the same block, and probably should be termed Talkeetna superterrane of Csejtey and others (1982). Minor differences in lithology can be explained by facies change in the nearly $700 \mathrm{~km}$ separation between areas of exposure. The Triassic red beds of the Chulitna terrane are distinctly different and probably represent a discreet block.

Lower Jurassic strata have been faunally identified in most of the 
southern Alaska terranes (Fig. 2). The fauna is mainly pandemic, but distinct realms can be determined from the non-pandemic forms (Figs. 4-7). Ammonites associated with the Tethyan Realm predominate and are present in all terranes indicating deposition at low latitudes. Elements off the East Pacific Realm in the Sinemurian and Pliensbachian Stages indicate a paleolongitude in the eastern Pacific. Amaltheus in the Peninsular Terrane suggests that the terrane had started northward by the Pliensbachian Stage because that genus is restricted to the Boreal Realm; however, it is present in only one collection in the southern Alaska terranes and may be possibly an aberrant specimen.

The Middle Jurassic was a time of great faunal productivity and diversity in the southern Alaska allochthonous terranes. Elements of several realms are commonly intermingled at the stage level (Figs. 8-14), but a very specific pattern was developing. Tethyan Realm genera ubiquitous in the Triassic and common in lower Jurassic strata, continue modestly into the lower Bajocian and then completely disappear from southern Alaskan terranes. At the same time, elements of the Boreal Realm are rapidly increasing including both Boreal and Bering Provinces. The Bering Province is important for longitude as well as latitude because this province was restricted to northeastern Pacific areas (Taylor and others, 1984).

The Cretaceous fauna indicate that the terranes continued to be in the northeastern Pacific (Figs. 16-20). The bivalve Buchia was a major faunal element until the Valanginian Stage. Several species are present, and all lived in a shallow-water shelf environment. Open marine conditions were reestablished in the Hauterivian and ammonites were once again a major part of the fauna, but only forms indigenous to the northeast Pacific were present at first. Ultimately a few pandemic forms appeared, but low-latitude Tethyan ammonites were absent. 
Armstrong, A.K., and MacKevett, E.M., Jr., 1982, Stratigraphy and diogenetic history of the lower part of the Triassic Chitistone Limestone: U.S. Geological Survey Professional Paper 1212-A, p. A1-A26.

Berg, H.C., Jones, D.L., and Coney, P.J., 1978, Map showing pre-Cenozoic tectonostratigraphic terranes of southwestern Alaska and adjacent areas: U.S. Geological Survey Open-File Report 78-1085.

Callomon, J.H., 1984, A review of the biostratigraphy of the post-lower Bajocian Jurassic ammonites of western and northern North America; in Westermann, G.E.G., ed., Jurassic-Cretaceous biochronology and paleogeography of North America: Geological Association of Canada Special Paper 27, p. 143-174.

Coe, R.S., Globerman, B.R., Plumley, P.W., and Thrupp, G.A., 1985, Paleomagnetic results from Alaska and their tectonic implications, in Howel1, D.G., ed., Tectonostratigraphic terranes of the Circum-Pacific region: Circum-Pacific Council for energy and mineral resources Earth Science Series No. 1, p. 85-109.

Coney, P.J., Jones, D.L., and, Monger, H.W.H., 1980, Cordilleran Suspect Terranes: Nature, v. 288, p. 329-333.

Connelly, William, and Moore, J.C., 1979, Geologic map of the northwest side of Kodiak Island, and adjacent islands: U.S. Geological Survey Miscellaneous Field Studies Map MF-1057, scales $1: 250,000$ and $1: 63,360$.

Csejtey, Bella, Jr., Cox, D.P., Evarts, R.C., Stricker, G.D., and Foster, H.L., 1982, The Cenozoic Denali fault system and the Cretaceous accretionary development of southern Alaska: Journal of Geophysical Research, v. 87, n. B5, p. 3741-3754.

Csejtey, Bèla, Jr., Nelson, W.H., Jones, D.L., Silberling, N.J., Dean, R.M., Morris, M.S., Lanphere, M.A., Smith, J.G., and Silberman, M.L., 1978, Reconnaissance geologic map and geochronology Talkeetna Mountains quadrangle, northern part of Anchorage quadrangle, and southwest corner of Healy quadrangle Alaska: U.S. Geological Survey Open-File Report 78558 A.

Detterman, R.L., Case, J.E., Miller, J.W., Wilson, F.H., and Yount, M.E., 198_. Stratigraphic framework of the Alaska Peninsula: U.S. Geological Survey Bulletin _, (in review)

Detterman, R.L., Case,J.E., Wilson, F.H., and Yount, M.E., 1987, Geologic Map of the Ugashik, Bristol Bay, and part of Karluk quadrangles Alaska: U.S. Geological Survey Miscellaneous Geologic Investigations Map, I-1685.

Detterman, R.L., and Hartsock, J.K., 1966, Geology of the Iniskin-Tuxedni Region, Alaska: U.S. Geological Survey Professional Paper 512, $78 \mathrm{p}$.

Detterman, R.L., Miller, J.W., and Case, J.E., 1985, Stratigraphic sections, megafossil checklists, and locality data from Ugashik and part of Karluk quadrangles, Alaska: U.S. Geological Survey Miscellaneous Field Studies Map MF 1539B.

Detterman, R.L., Miller, T.P., Yount, M.E., and Wilson, F.H., 1981a, Geological map of the Chignik and Sutwik Island quadrangles, Alaska: U.S. Geological Survey Miscellaneous Geologic Investigation Map I-1229.

Detterman, R.L., and Reed, B.L., 1980, Stratigraphy, structure, and economic geology of the Iliamna quadrangle, Alaska: U.S. Geological Survey Bulletin 1368-B, 86 p.

Detterman, R.L., Reiser, H.N.. Brosgé, W.P., and Dutro, J.T., Jr., 1975, Post- 
Carboniferous stratigraphy, norhteastern Alaska: U.S. Geological Survey Professional Paper 886, 46 p.

Detterman, R.L., Yount, M.E., and Case, J.E., 1981b, Megafossil checklists, locality data, and stratigraphic sections from Chignik and Sutwik Island quadrangles, Alaska: U.S. Geological Survey Miscellaneous Field Studies Map MF-1053N.

Grantz, Arthur, 1960, Geologic map of the Talkeetna Mountains (A-2) quadrangle, Alaska, and contiguous areas to the north and northwest: U.S. Geological Survey Miscellaneous Investigations Map I-313. , 1961, Geologic map of the Anchorage (D-2) quadrangle, Alaska. Geologic map of north two-thirds of the Anchorage (D-1) quadrangle, Alaska: U.S. Geological Survey Miscellaneous Geologic Investigations Map I-343.

Hillhouse, J.W., 1977, Paleomagnetism of the Triassic Nikolai Greenstone, south-central Alaska: Canadian Journal Earth Sciences, v. 14, p. 25782592.

Hillhouse, J.W., and Gromme, C.S., 1982, Limits to the northward drift of the Paleocene Cantwell Formation, central Alaska: Geology, v. 10, p. 552556 .

, 1985, Paleomagnetism of sedimentary rocks Prince William and Yakutat Terranes, in Bartsch-Winkler, Susan, ed., The United States Geological Survey in Alaska: Accomplishments during 1984: U.S. Geological Survey Circular 967, p. 60-61.

Hillhouse, J.W. Gromme, C.S., and Csejtey, Bèla, 1984, Paleomagnetism of Early Tertiary volcanic rocks in the northern Talkeetna Mountains; in Reed, K.M., and Bartsch-Winkler, Susan, eds; United States Geological Survey in Alaska: Accomplishments during 1982: U.S. Geological Survey Circular 939 , p. 50-52.

Hoare, J.M., and Coonrad, W.L., 1978, Geologic map of the Goodnews and Hagemeister Island quadrangle regions, southwestern Alaska: U.S. Geological Survey Open-File Report 78-9-B, 2 sheets, scale 1:250,000. Imlay, R.W., 1953, Callovian Jurassic ammonites from the United States and Alaska: U.S. Geological Survey Professional Paper 249-B, p. B41-B108. Imlay, R.W., 1959, Succession and speciation of pelecypod Aucella (Buchia): U.S. Geological Survey Professional Paper 314-G, p. G155-G169. 1960, Early Cretaceous (Albian) ammonites from Chitina Valley and Talkeeetna Mountains, Alaska: U.S. Geological Survey Professional Paper 354-D, D87-D113.

, 1961 New genera and subgenera of Jurassic (Bajocian) ammonites from Alaska: Journal of Paleontology, v. 35, p. 467-474.

- 1964, Middle Bajocian ammonites from the Cook Inlet region, Alaska:

U.S. Geological Survey Professional Paper 418B, p. B1-B61.

, 1980a, Middle Jurassic (Bathenian) ammonites from southern Alaska:

U.S. Geological Survey Professional Paper 1091, $42 \mathrm{p}$.

- 1980b, Jurassic paleobiogeography of conterminous United States in its continental setting: U.S. Geological Survey Professional Paper 1062, 134 p.

1981, Early Jurassic ammonites from Alaska: U.S. Geological Survey Professional Paper 1148, 49 p.

- 1984a, Jurassic ammonite succession in North America and biographic implications; in Westermann, G. E. G., ed; Jurassic-Cretaceous biogeography and paleogeography of North American Geological Association of Canada Special Paper 27, p

, 1984b, Early and middle Bajocian (Middle Jurassic) ammonites from southern 
Alaska: U.S. Geological Survey Professional Paper 1322, 38 p.

Imlay, R.W., and Detterman, R.L., 1973, Jurassic paleobiography of Alaska: U.S. Geological Survey Professional Paper 801, 34 p.

Jeletsky, J.A., 1965, Late Jurassic and Early Cretaceous fossil zones of the Canadian western Cordillera, British Columbia: Canada Geological Survey Bulletin 103, $70 \mathrm{p}$.

Jones, D.L., 1963, Upper Cretaceous (Campanian and Maestrichtian) ammonites from southern Alaska: U.S. Geological Survey Professional Paper 432, 53 p. , 1967, Cretaceous ammonites from the lower part of the Matanuska Formation southern Alaska, with a stratigraphic summary by Arthur Grantz: U.S. Geologicl Survey Professional Paper 547, 49 p.

, 1973, Structural elements and biostratigraphic framework of Lower

Cretaceous rocks in southern Alaska, in Casey, R., and Rawson, P. F., eds., The Boreal Lower Cretaceous: Seel House Press, Liverpool, p. 1-18.

Jones, D.L., Bailey, E.H., and Imlay, R.W., 1969, Structural and stratigraphic significance of the Buchia zones in the Colyear Springs-Paskenta area, California: U.S. Geological Survey Professional Paper 647-A, p. A1-A23.

Jones, D.L., and Clark, S.H.B., 1973, Upper Cretaceous (Maestrichtian) fossils from the Keni-Chugach Mountains, Kodiak and Shumagin Islands, southern Alaska: U.S. Geological Survey Journal of Research, v. 1, no. 2, p. 125136.

Jones, D.L., Silberling, N.J., Berg, H.C., and Plafker, George, 1981, Map showing tectonostratigraphic terranes of Alaska, columnar sections, and summary descriptions of terranes: U.S. Geological Survey Open-File Report 81-792, 20 p., 2 sheets.

Jones, D.L., Silberling, N.J., Csejtey, Bela, Jr., Nelson, W.H., and Blome, C.D., 1980, Age and structural significance of ophiolite and adjoining rocks in the upper Chulitna District, South-central Alaska: U.S. Geological Survey Professional Paper 1121A, p. A1-A21.

Jones, D.L., Silberling, N.J., and Hillhouse, J.W., 1977, Wrangellia - a displaced terrane, in northwestern North America: Canadian Journal Earth Sciences, v. 14, p. 2565-2577.

, 1978, Microplate tectonics of Alaska - significance for the Mesozoic history of the Pacific Coast of North America; in Howe11, D.G., and McDougal1, K.A., eds., Mesozoic paleogeography of western United States: Society of Economic Paleontologists and Mineralogists, Pacific Coast Pal eogeography symposium, v. e, p. 71-74.

Kiente, Juergen, and Turner, D.L., 1976, The Shumagin-Kodiak batholith - a Paleocene magmatic arc: State of Alaska Department of Natural Resources, Geology Report 51, p. 9-11.

MacKevett, E.M., Jr., 1971, Stratigraphy and general geology of the McCarthy C-5 quadrangle, Alaska: U.S. Geological Survey Bulletin 1323, 35 p. , 1978, Geologic map of the McCarthy quadrangle, Alaska: U.S. Geological Survey Miscellaneous Investigations Map I-1032, scale 1:250,000.

Martin, G.C., 1926, The Mesozoic stratigraphy of Alaska: U.S. Geological Survey Bulletin 776, $493 \mathrm{p}$.

Miller, J.W., and Detterman, R.L., 1985, The Buchia zones in Upper Jurassic rocks on the Alaska Peninsula, in Bartsch-WinkTer, Susan, and Reed, K.M., eds., The United States Geological Survey in Alaska: U.S. Geological Survey Circular 945, p. 51-53.

Moore, G.W., 1982, Plate-tectonic map of the Circum-Pacific region-explanatory note: Tulsa, OK., American Association of Petroleum Geologists, 14

Moore, R.C., 1959, Treatise on Invertebrate Paleontoloty: Geological Society of 
America and University of Kansas, Part L, Mollusca 4, Cephalopod-Ammonoidea, $471 \mathrm{p}$.

Nickols, K.M., and Silberling, N.J., 1979, Early Triassic (Smithian) ammonites of paleoequatorial affinity from Chulitna terrane, South-central Alaska: U.S. Geological Survey Professional Paper 1121-B, p. B1-B5.

Packer, D.R., and Stone, D.B., 1974, Paleomagnetism of Jurassic rocks from southern Alaska and the tectonic implications: Canadian Journal Earth Sciences, v. 11, p. 976-997.

Panuska, B.C., and Stone, D.B., 1985, Latitudinal motion of the Wrangellia and Alexander Terranes and the southern Alaska Superterrane, in Howe11, D.G., ed., Tectonostratigraphic terranes of the Circum-Pacific Region: CircumPacific Council for energy and mineral resources Earth Science Series no. 1, p. 109-121.

Plafker, George, Jones, D.L., and Pessagno, E.A., Jr., 1977, A Cretaceous accretionary flysch and melange terrane along the Gulf of Alaska margin in Bleam, K.M., ed., The United States Geological Survey in Alaska:

Accomplishments during 1976: U.S. Geological Survey Circular 75HB, p. B41B42.

Plumley, P.W., Coe, R.S., and Byrne, Tim, 1983, Paleomagnetism of the Paleocene Ghost Rocks Formation, Prince William Terrane, Alaska: Tectonics, v. 2, p. 295-314

Poulton, T.P., 1978, Pre-Late 0xfordian Jurassic biostratigraphy of northern Yukon and adjacent Northwest Territories: Geological Association of Canada Special Paper 18, p. 445-466.

Reed, B.L., and Nelson, S.W., 1977, Geologic map of the Talkeetna quadrangle, Alaska: U.S. Geological Survey Miscellaneous Field Studies Map, MF-870A.

Richter, D.H., 1976, Geologic map of the Nabesna quadrangle, Alaska: U.S. Geologcal Survey Miscellaneous Investigations Map I-932.

Riehle, J.R., Detterman, R.L., Yount, M.E., and Miller, J.W., 1987, Preliminary geologic map of the Mount Katmai quadrangle, and portions of the Afognak and Naknek quadrangles, Alaska: U.S. Geological Survey OpenFile Report 87-593.

Silberling, N,J,, 1985, Biographic significance of the Upper Triassic bivalve - Monotis in Circum-Pacific accreted terranes; in Howel1, D.G., ed., Tectonostratigraphic terranes of the Circum-Pacific Regioin: CircumPacific Region: Circum-Pacific Council for energy and mineral Series

Stone, D.B., Panuska, B.C., and Packer, D.R., 1982, Paleolatitudes versus time for southern Alaska: Journal of Geophysical Research, v. 87, p. 36973707 .

Stone, D.B., and Packer, D.R., 1977, Tectonic implications of Alaska Peninsula paleomagnetism data: Tectonophysics, v. 37, p. 183-201. , 1979, Paleomagnetic data from the Alaska Peninsula: Geological Society of America Bulletin, v. 90, p. 545-560

Taylor, D.C., Callomon, J.H., Hall, R., Smith, P.L., Tipper, H.W., and Westermann, G.E.G., 1984, Jurassic ammonite biogeography of western North America - The tectonic implications; in Westermann G.E.G., ed., JurassicCretaceous biochronology and paleogeography of North America: Geological Association of Canada Special Paper 27, p. 121-141.

Westermann, G.E.G., 1964, The ammonoid fauna of the Kialagvik Formation at Wide Bay, Alaska Peninsula, Part I, Lower Bajocian (Aalenian): Bulletin of American Paleontology, v. 47, p. 325-503. , 1969, The ammonoid fauna of the Kialagvik Formation at Wide Bay, Alaska Peninsula, Part II, Sanninia Sowerbyi Zone (Bajocian) Bulletin of 
American Paleontology, v. 57, 226 p.

Westermann, G.E.G., 1981, Ammonite biochronology and biogeography of the Circum-Pacific Middle Jurassic; 1981, in House, M.R., and Senior, J.R., eds., The Ammonite Systematic Association Special Volume, n. 18, p. 459498.

Wilson, F.H., Detterman, R.L., and Case, J.E., 1985, the Alaska Peninsula Terrane; a definition: U.S. Geological Survey Open-File Report 85-450, $17 \mathrm{p}$.

Wilson, F.H., Detterman, R.L., and Harris, E.E., 198_, Generalized geologic map of Port Moller, Stepovak Bay, and Simeon of Island quadrangles, Alaska: U.S. Geological Survey Miscellaneous Field Studies Map MF-A (in review).

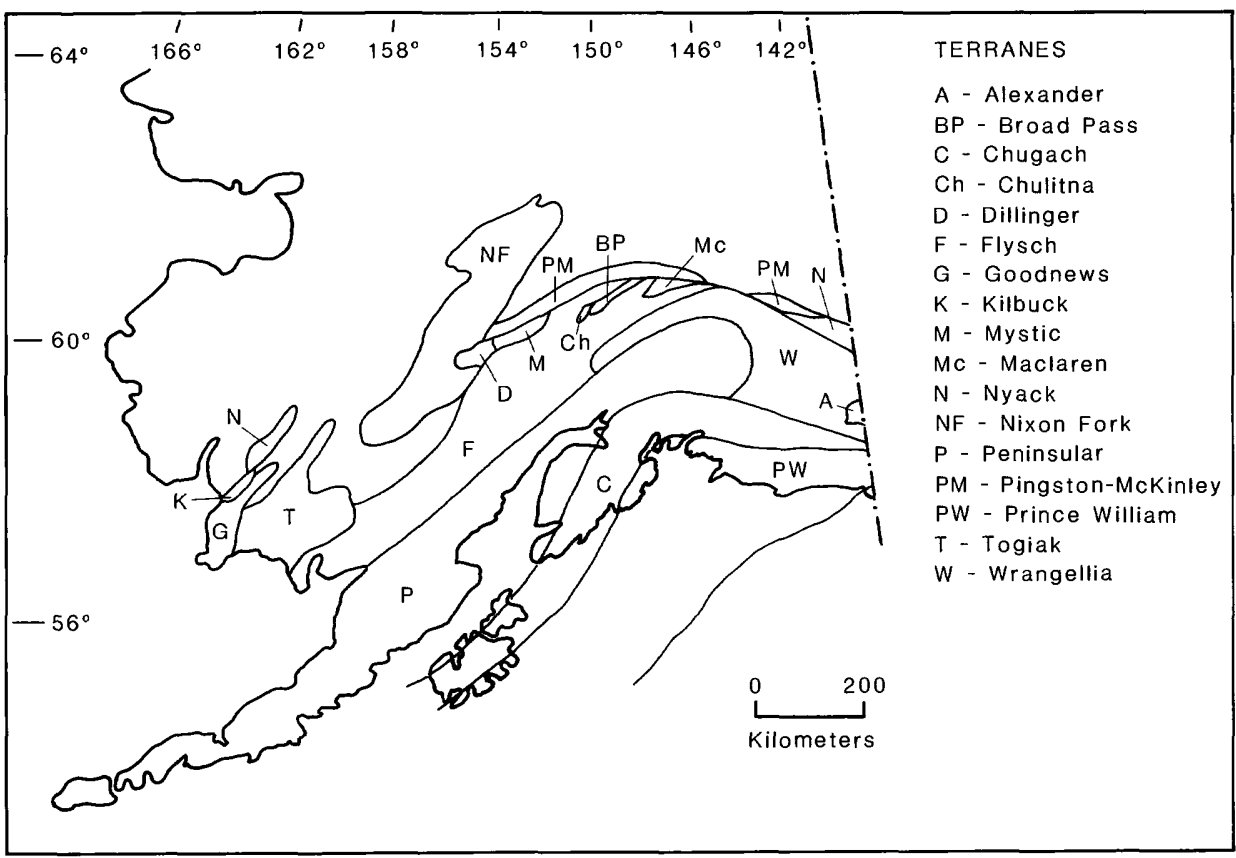

Figure 1. Tectonostratigraphic Terranes of Southern Alaska ( Modified after Jone's and others, 1981) 


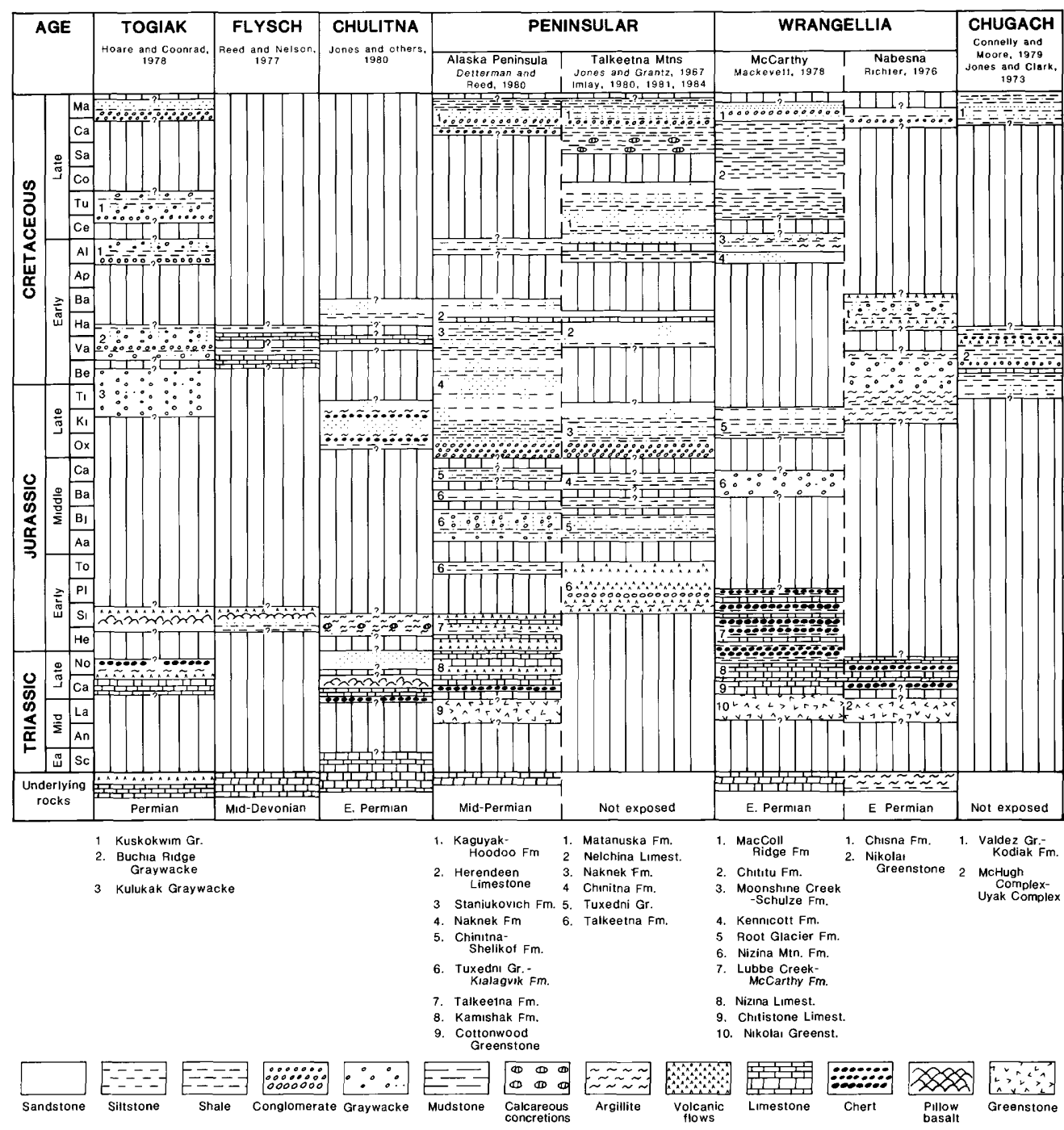

Figure 2. Schematic stratigraphic sections of seiected terranes of southern Alaska.

Vertical lines indicate missing strata No scale. 


\begin{tabular}{|c|c|c|}
\hline REALM & REGION & PROVINCE \\
\hline \multirow{3}{*}{ BOREAL } & & Boreal \\
\hline & & Sub-Boreal \\
\hline & & Bering \\
\hline TETHYAN & & Caribbean \\
\hline \multirow{2}{*}{ EAST PACIFIC } & \multirow{2}{*}{ North Cordilleran } & Athabascan \\
\hline & & Shoshonean \\
\hline & $\begin{array}{c}\text { INFORMAL } \\
\text { Pandemic } \\
\text { Pacific }\end{array}$ & \\
\hline
\end{tabular}

Figure 3. Biogeographic terminology for southern Alaska. Modified after Taylor and others, 1984.

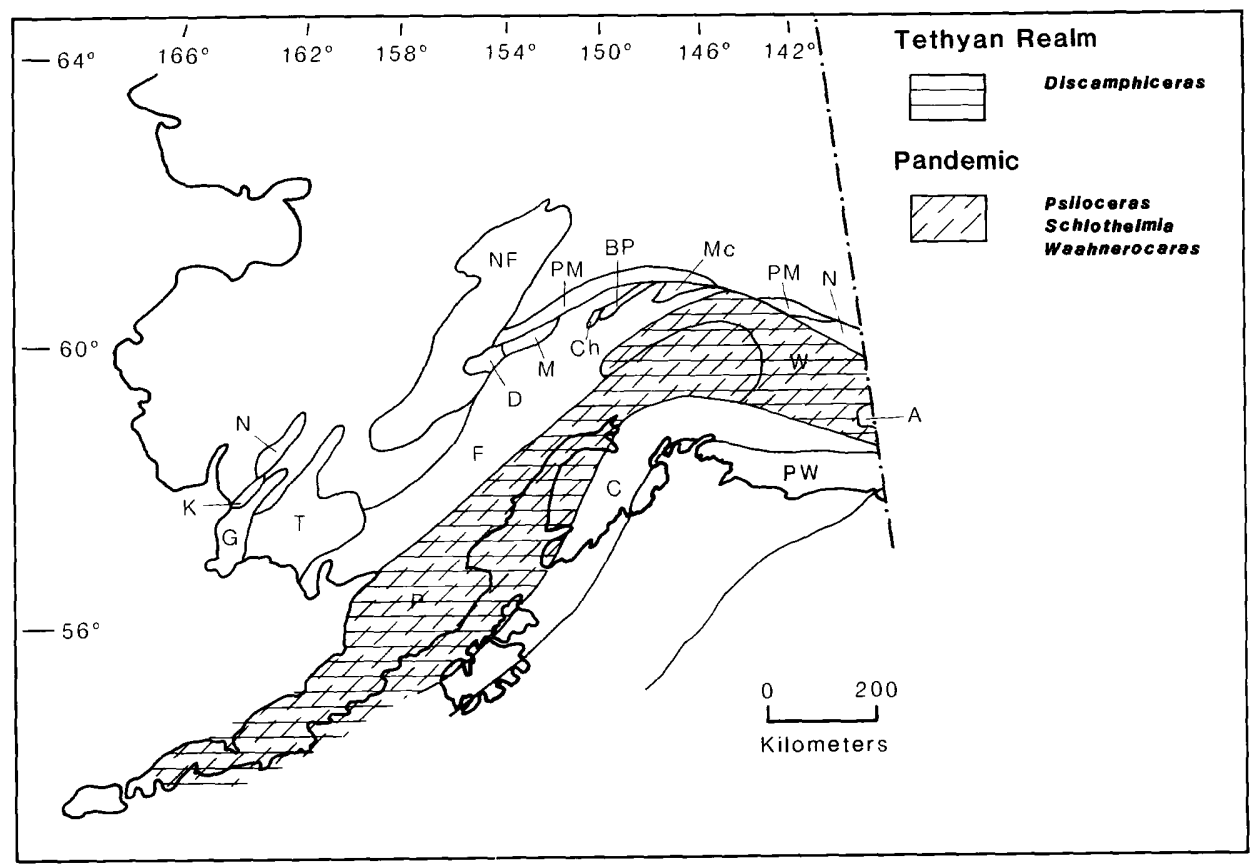

Figure 4. Hettangian Biogeography of Southern Alaska 


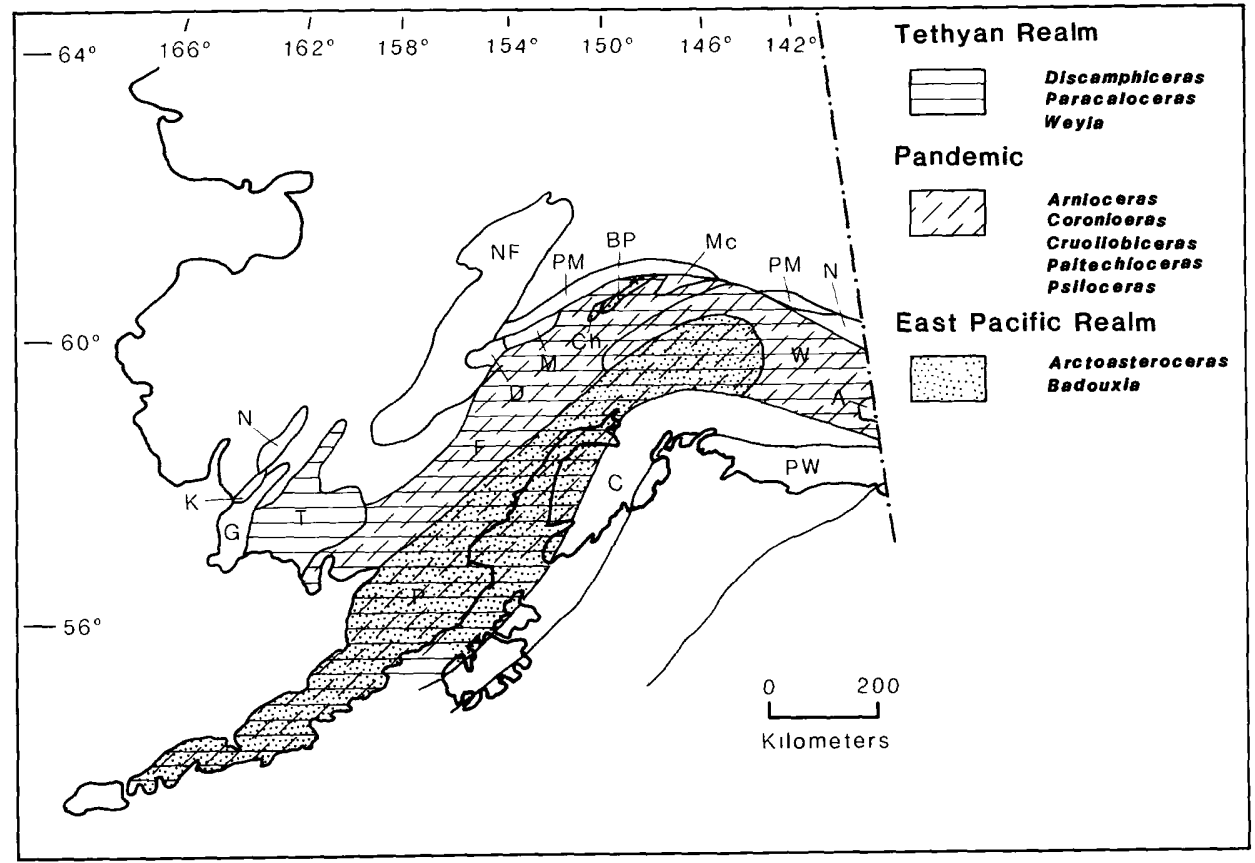

Figure 5. Sinemurian

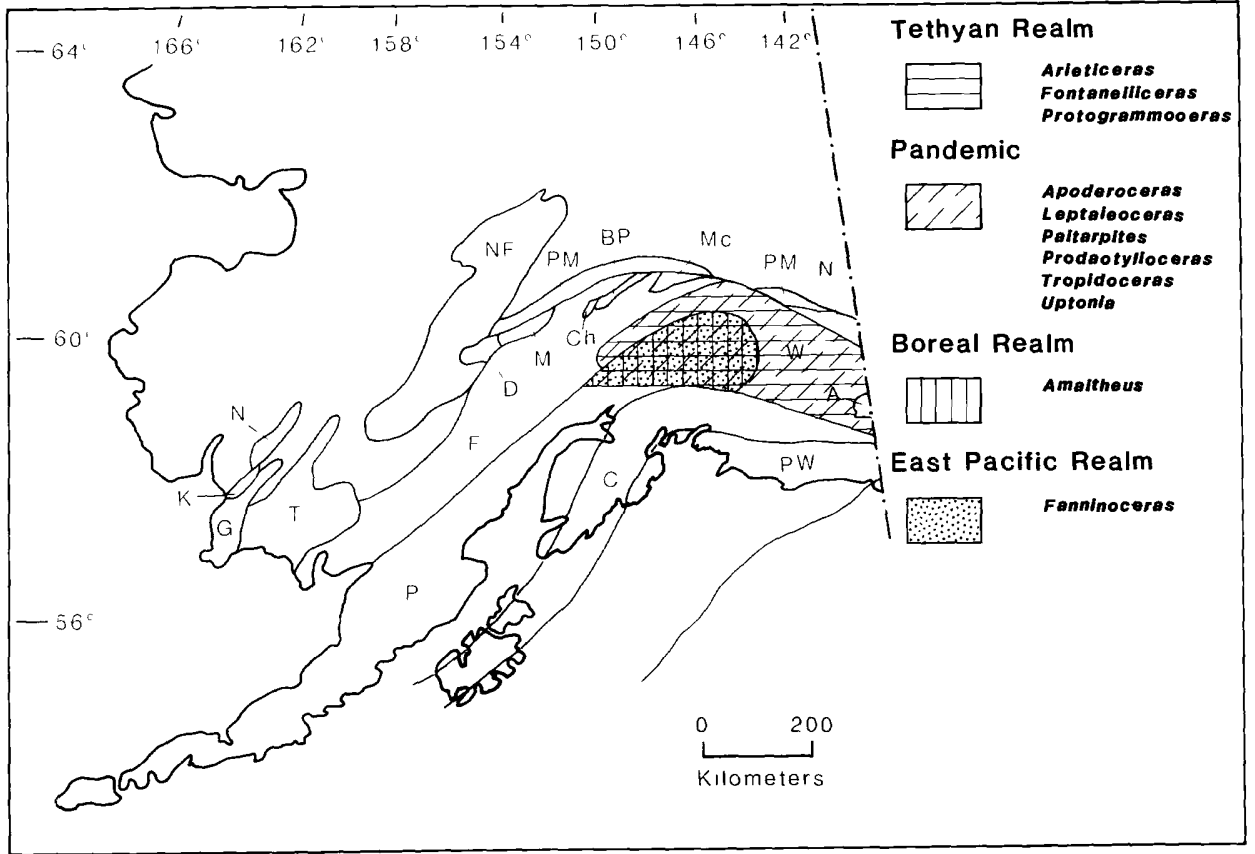

Figure 6. Pliensbachian 


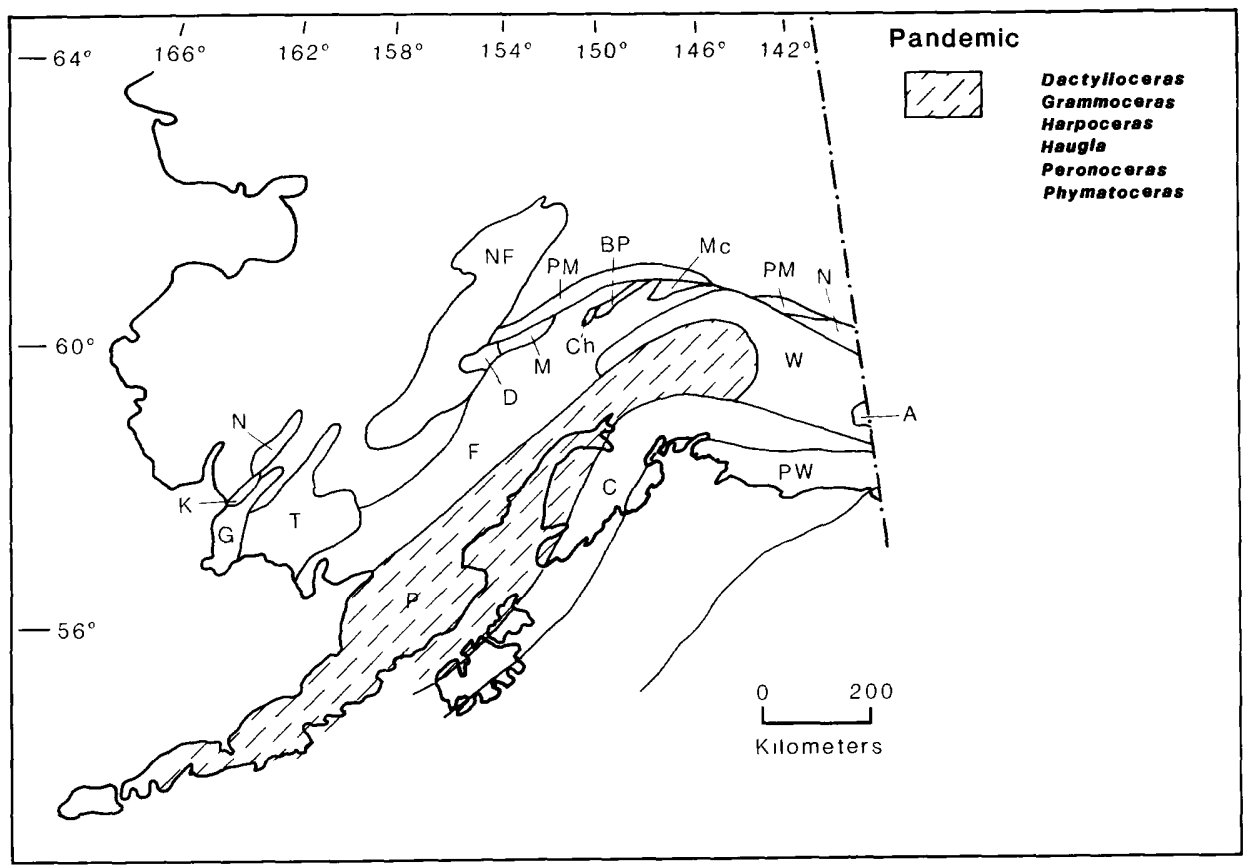

Figure 7. Toarcian

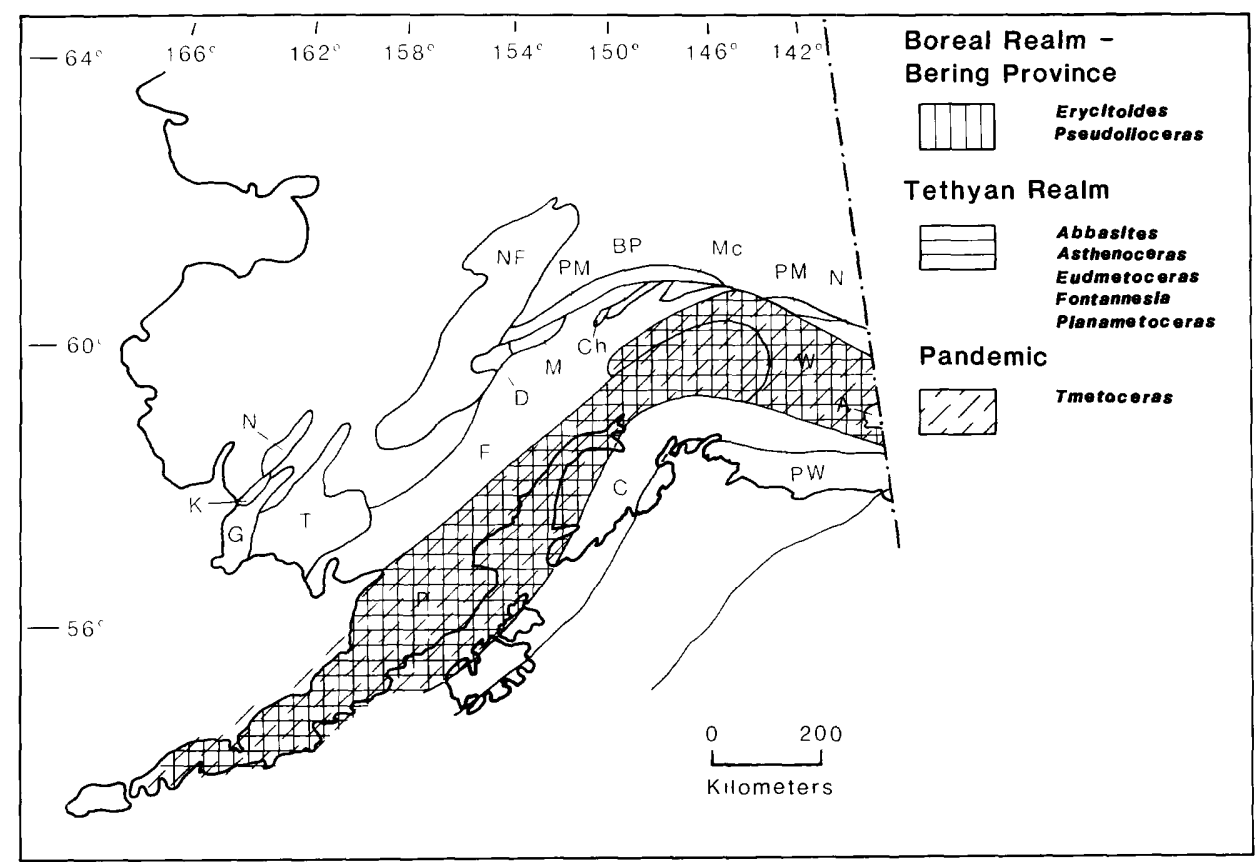

Figure 8. Aalenian 


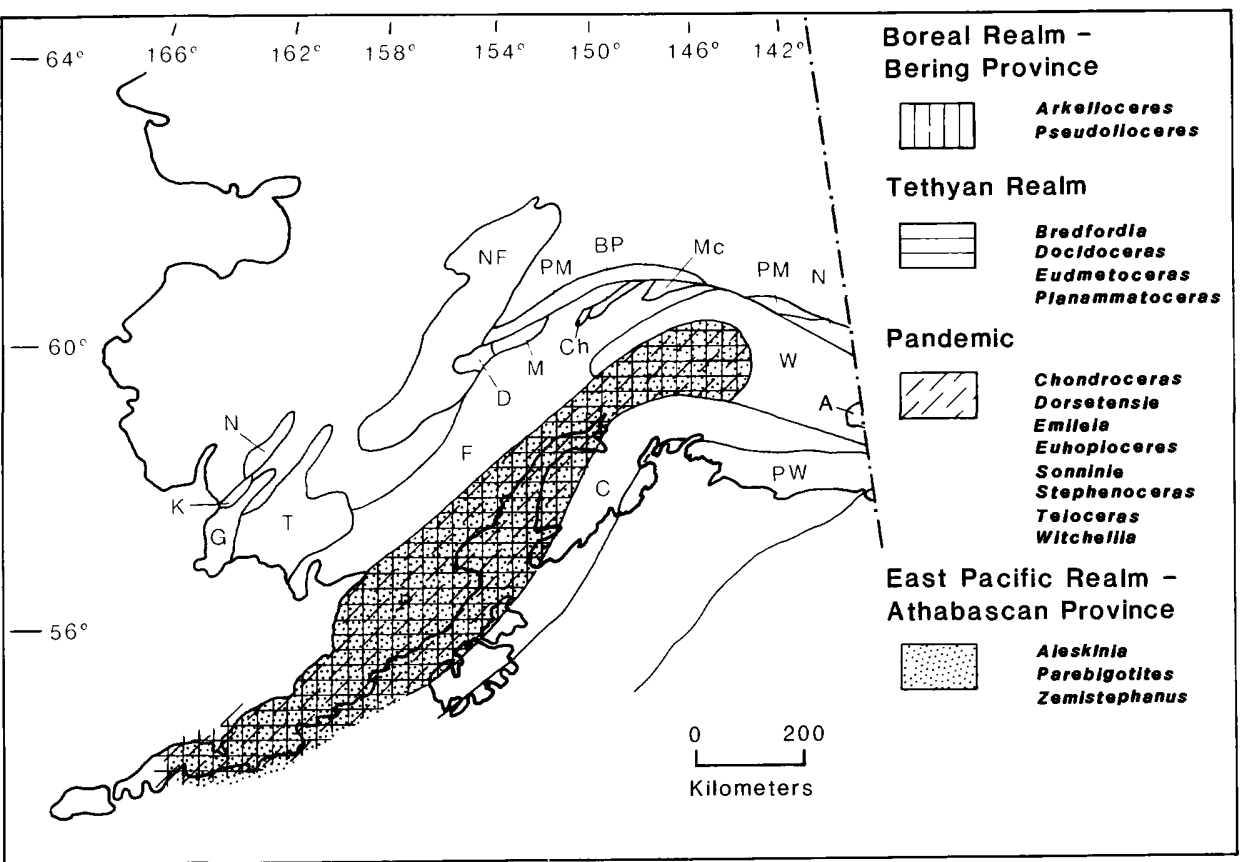

Figure 9. Early Bajocian

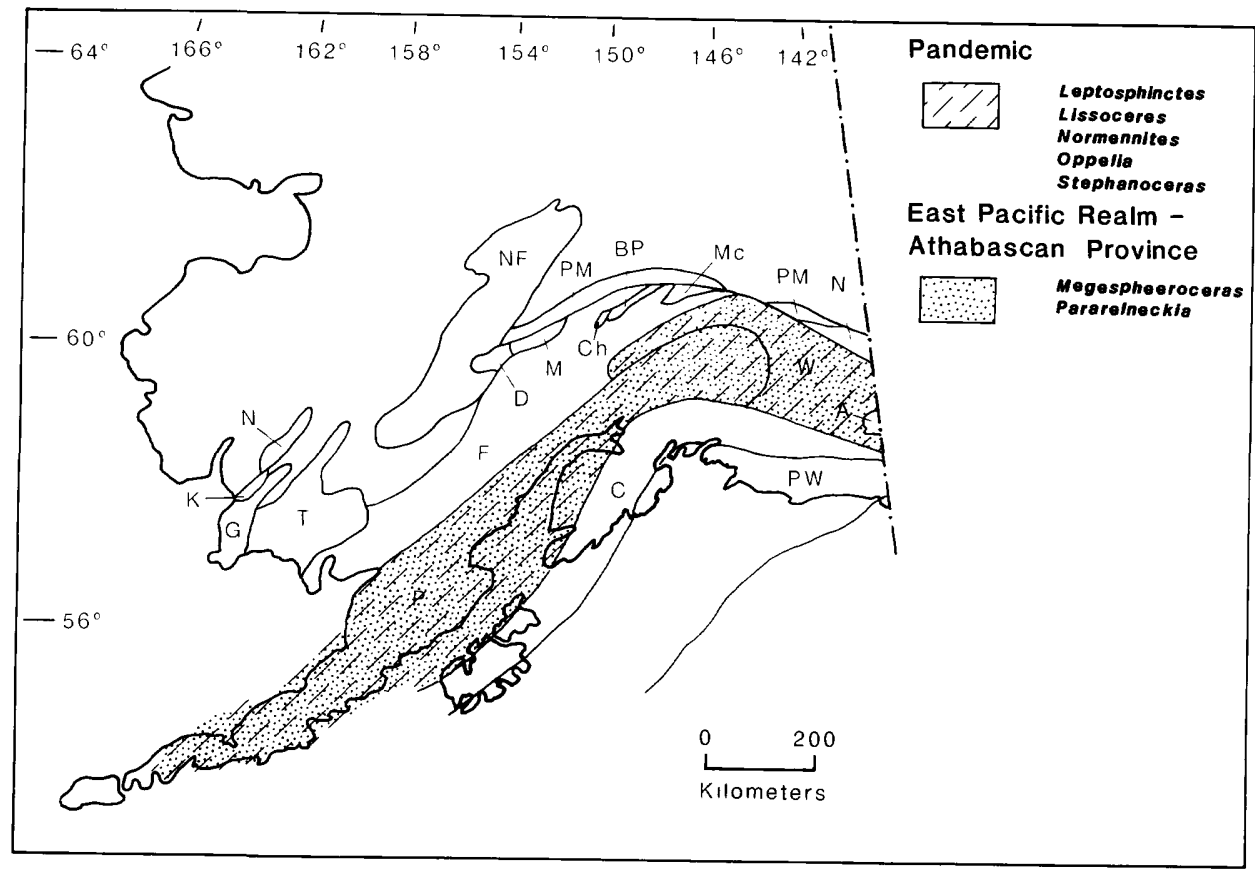

Figure 10. Late Bajocian 


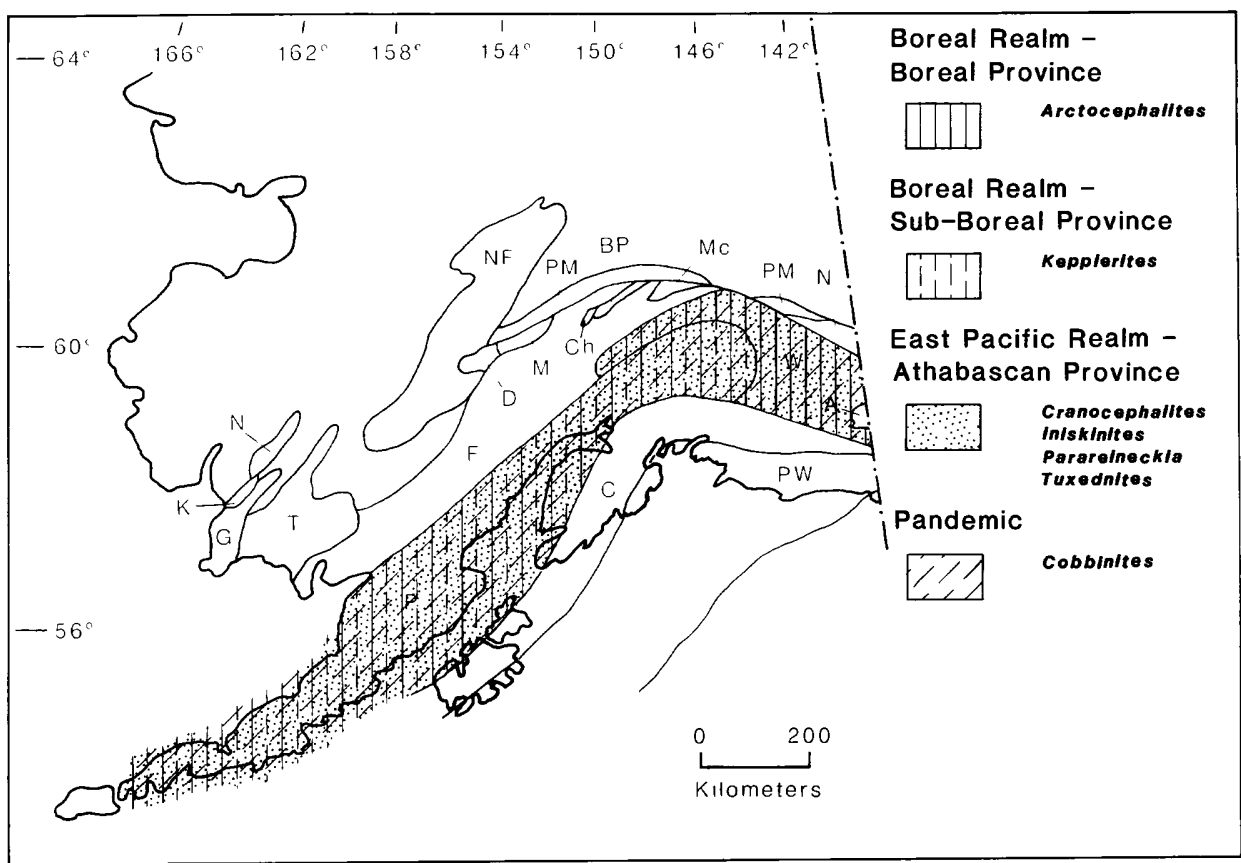

Figure 11. Early Bathonian

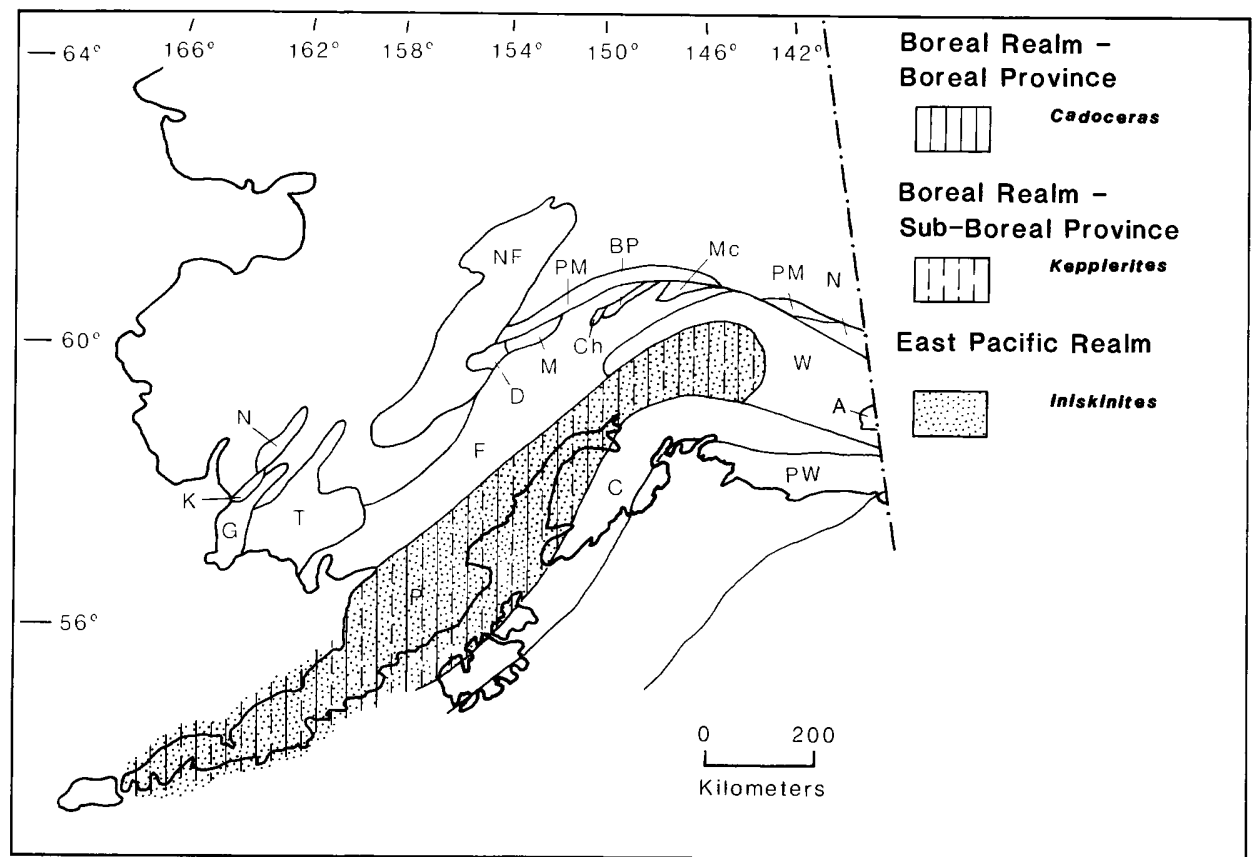

Figure 12. Late Bathonian 


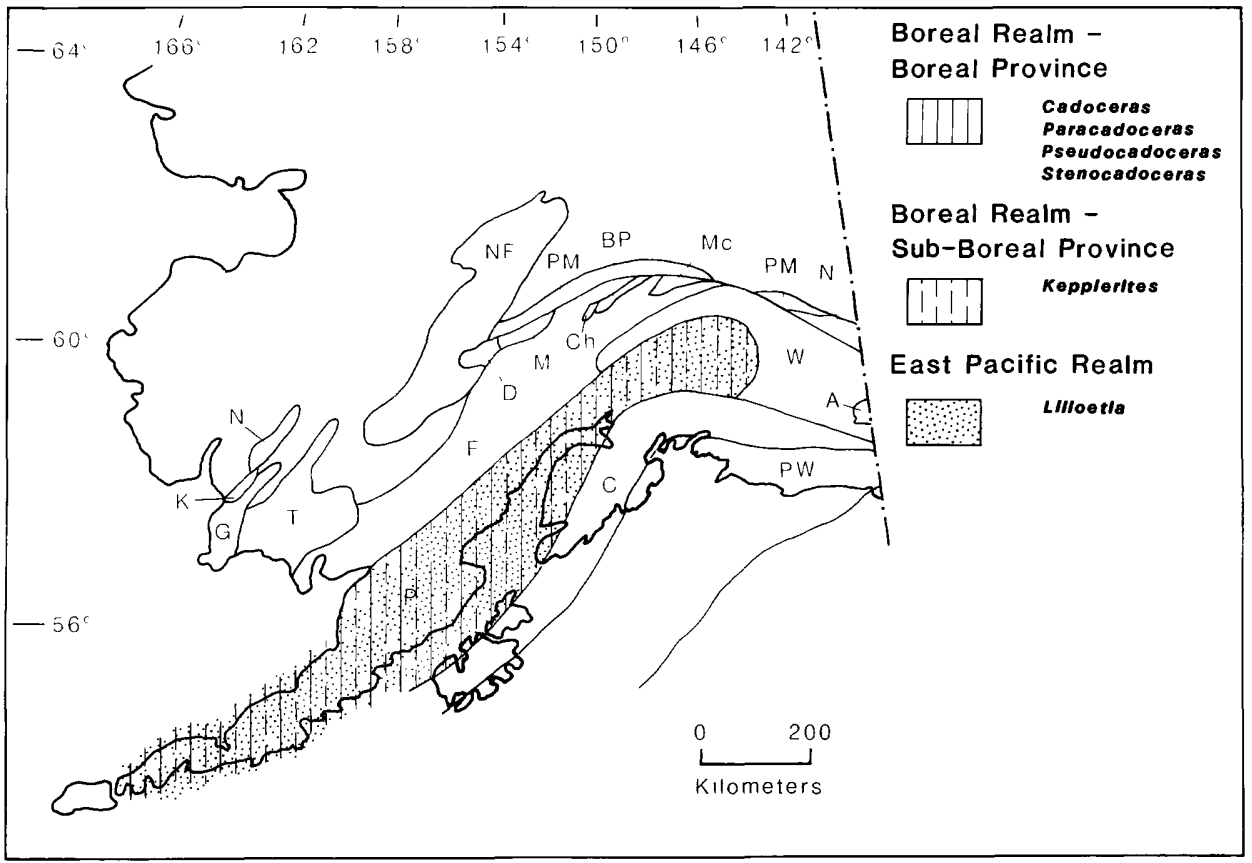

Figure 13. Callovian

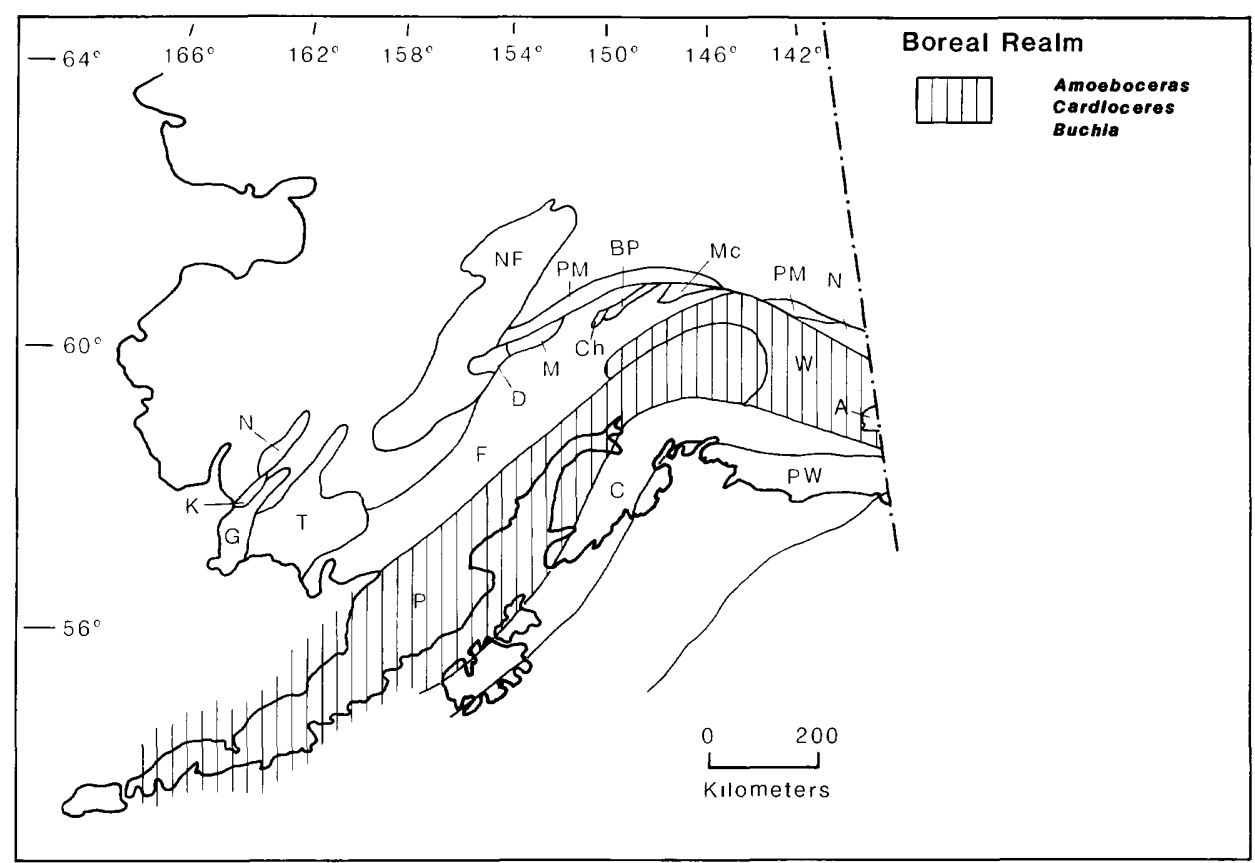

Figure 14. Oxfordian, Kimmeridgian, and Tithonian 


\begin{tabular}{|c|c|c|c|c|c|c|c|c|c|c|c|}
\hline \multirow{3}{*}{ System Series Stage } & \multicolumn{4}{|c|}{ LOWER CRETACEOUS } & \multicolumn{7}{|c|}{ UPPER JURASSIC } \\
\hline & \multicolumn{2}{|c|}{ Valanginian } & \multicolumn{2}{|c|}{ Berriasian } & \multicolumn{3}{|c|}{ Tithonian } & \multicolumn{2}{|c|}{ Kimmeridgian } & \multicolumn{2}{|c|}{ Oxfordian } \\
\hline & Late & Early & Late & Early & Late & Middle & Early & Late & Early & Late & Early \\
\hline \multicolumn{12}{|l|}{ Genus and Species } \\
\hline \multicolumn{12}{|l|}{ Buchia crassicollls sollda (Lahusen) } \\
\hline \multicolumn{12}{|l|}{ Buchla sublaevis Keyserling } \\
\hline \multicolumn{12}{|l|}{ Buchia uncitoldes (Paviow) } \\
\hline \multicolumn{12}{|l|}{ Buchia okensis Paviow } \\
\hline \multicolumn{12}{|l|}{ Buchla plochll (Gabb) } \\
\hline \multicolumn{12}{|l|}{ Buchia blanfordiana (Stolczka) } \\
\hline \multicolumn{12}{|l|}{ Buchla mosquensis (von Buch) } \\
\hline Buchla rugosa (Flscher) & & & & & & & & & & & \\
\hline Buchie concenterlca (sowerby) & & & & & & & & & & & \\
\hline
\end{tabular}

Figure 15. Buchia Biozones in Southern Alaska (Miller and Detterman, 1985)

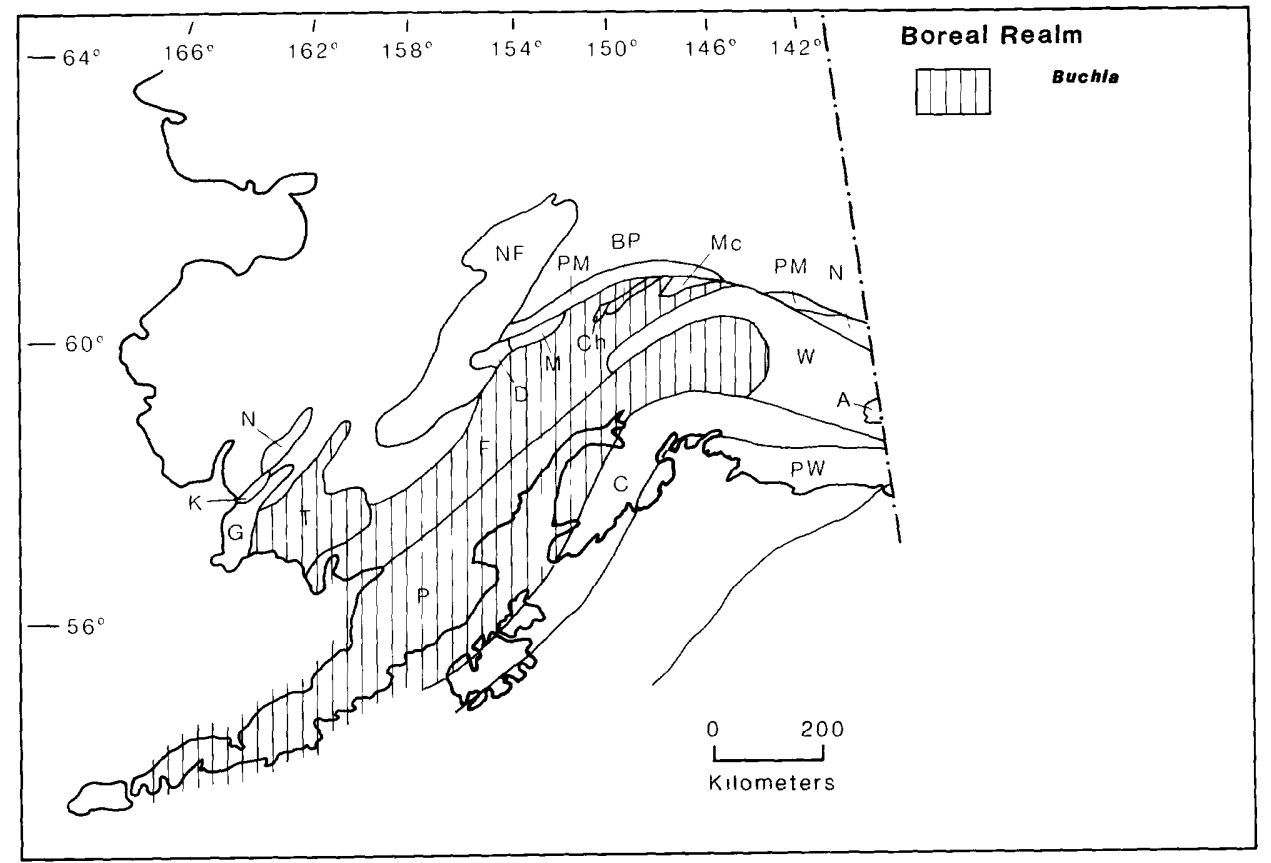

Figure 16. Berriasian and Valanginian 


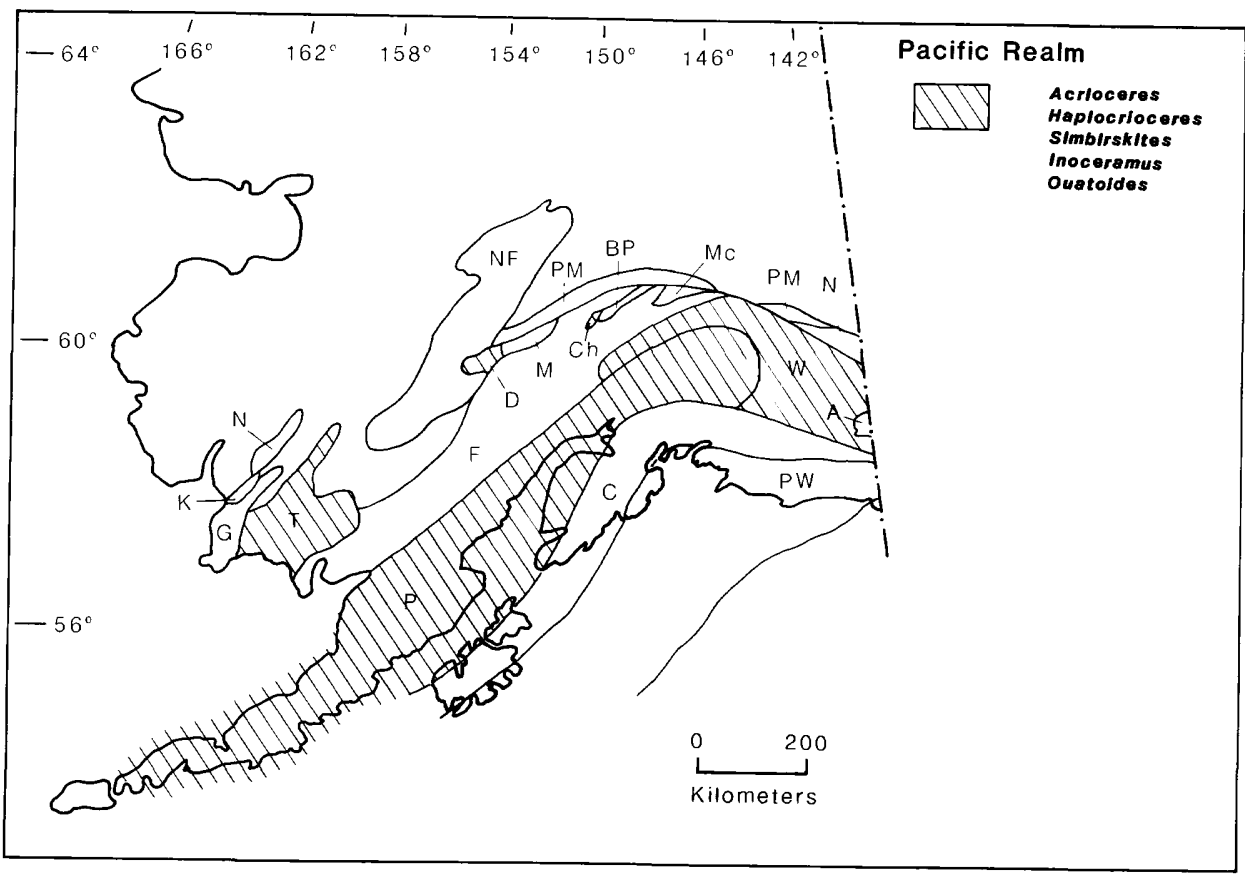

Figure 17. Hauterivian and Barremian

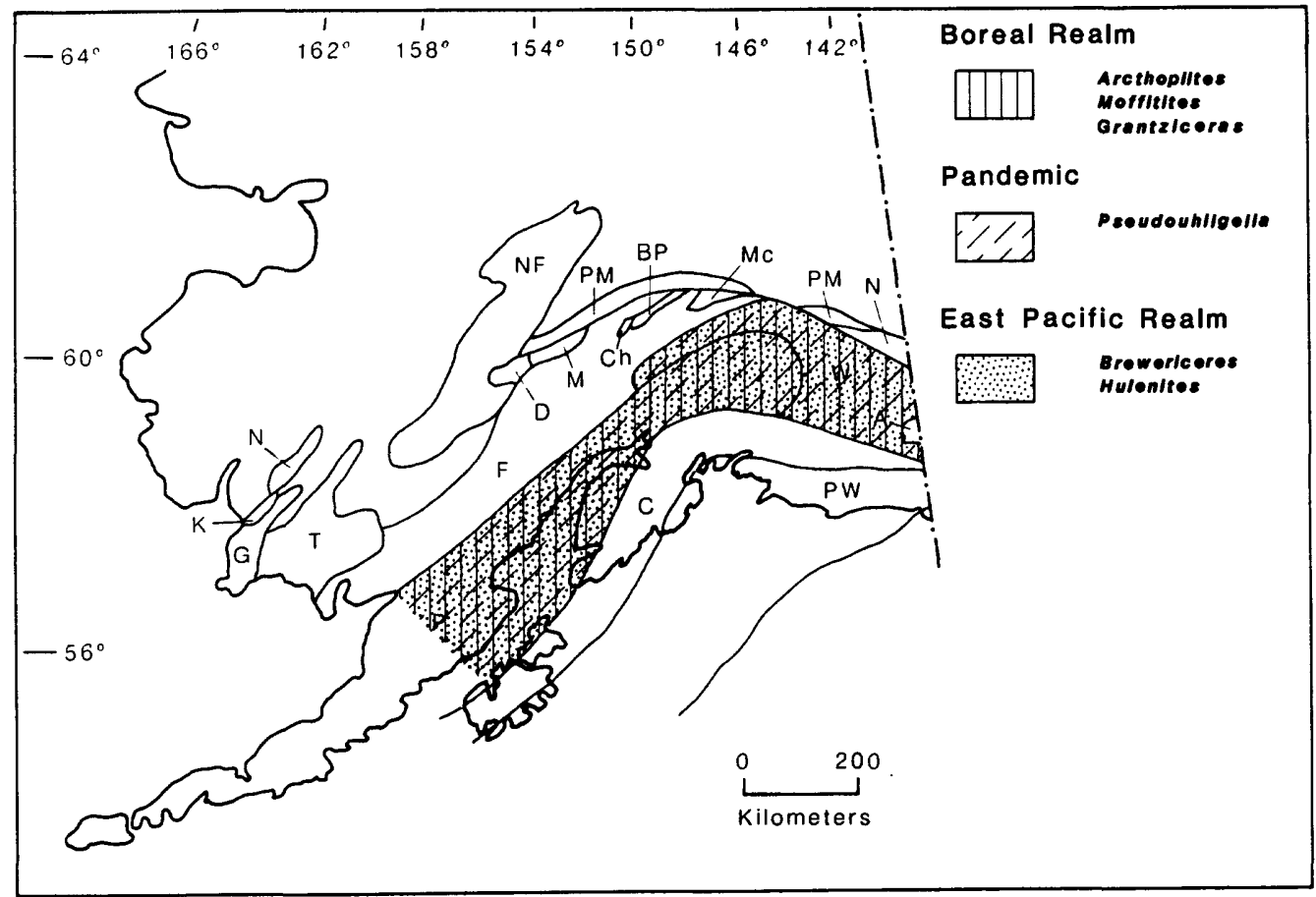

Figure 18. Albian 


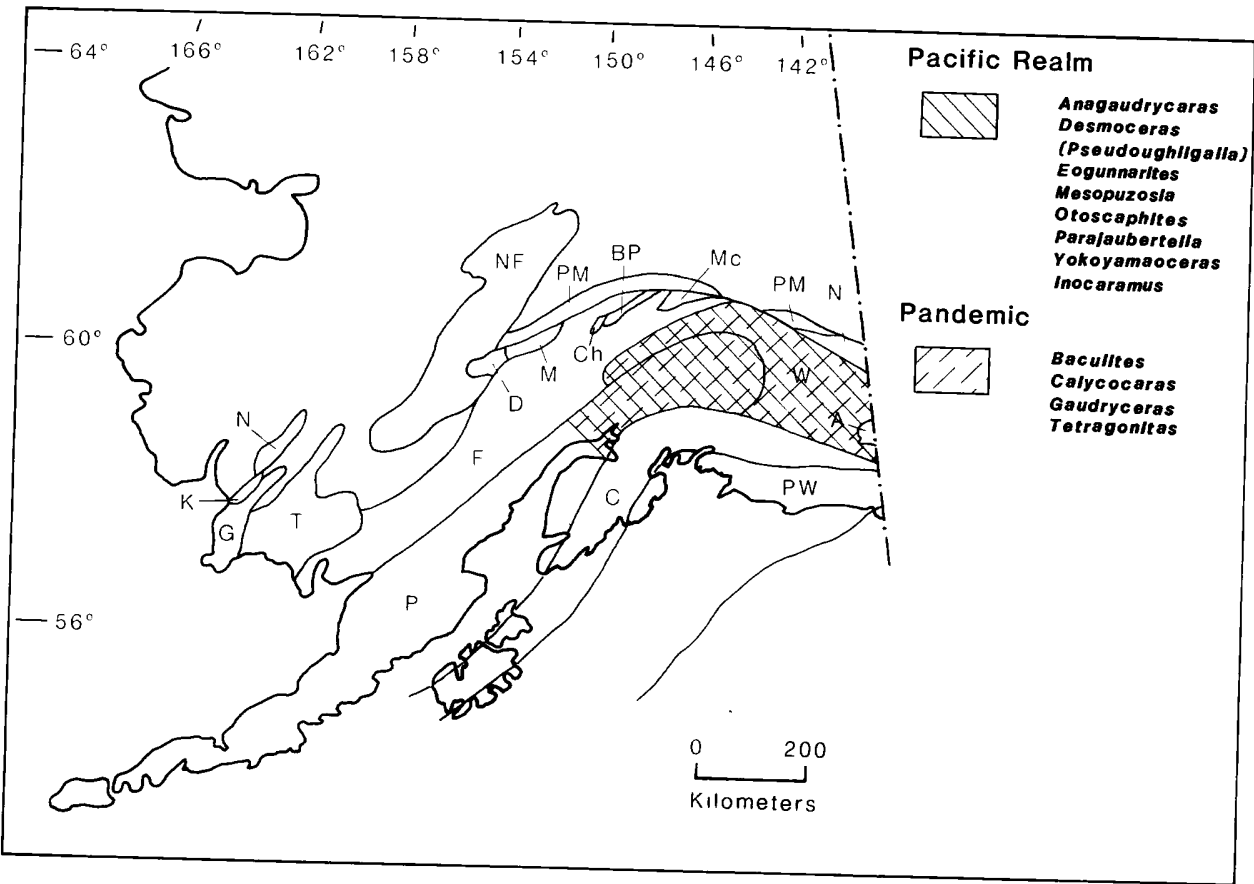

Figure 19. Cenomanian - Santonian

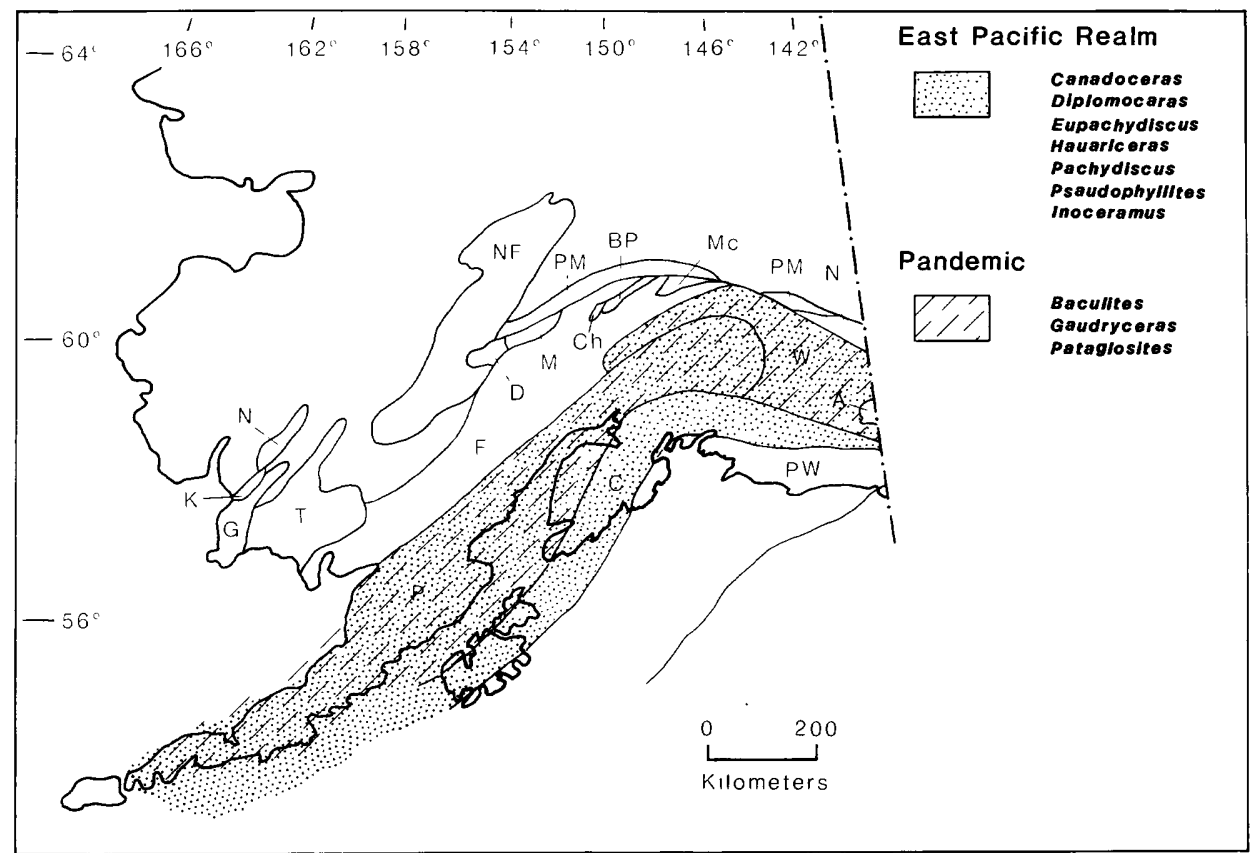

Figure 20. Campanian and Maastrichtian 